\title{
Anti-Cancer Effect of Panax Ginseng and Its Metabolites: From Traditional Medicine to Modern Drug Discovery
}

\author{
Sejin Kim ${ }^{1}{ }^{\mathbb{D}}$, Nayeon $\mathrm{Kim}^{1}{ }^{1}$, JaYeon Jeong ${ }^{1}$, Soojin Lee ${ }^{2}$, Woojin Kim ${ }^{3} \mathbb{D}$, Seong-Gyu Ko ${ }^{3}$ and \\ Bonglee Kim 1,3,4,*(D)
}

1 College of Korean Medicine, Kyung Hee University, 1 Hoegi-dong, Dongdaemun-gu, Seoul 05253, Korea; khkmksj@khu.ac.kr (S.K.); kimny26@khu.ac.kr (N.K.); jyjeong28@khu.ac.kr (J.J.)

2 Department of Clinical Korean Medicine, Graduate School, Kyung Hee University, 1 Hoegi-dong, Dongdaemun-gu, Seoul 05253, Korea; lettergr@khu.ac.kr

3 Korean Medicine-Based Drug Repositioning Cancer Research Center, College of Korean Medicine, Kyung Hee University, 1 Hoegi-dong, Dongdaemun-gu, Seoul 05253, Korea; wjkim@khu.ac.kr (W.K.); epiko@khu.ac.kr (S.-G.K.)

4 Department of Pathology, College of Korean Medicine, Kyung Hee University, 1 Hoegi-dong, Dongdaemun-gu, Seoul 130-701, Korea

* Correspondence: bongleekim@khu.ac.kr; Tel.: +82-2-961-9217

check for updates

Citation: Kim, S.; Kim, N.; Jeong, J.; Lee, S.; Kim, W.; Ko, S.-G.; Kim, B. Anti-Cancer Effect of Panax Ginseng and Its Metabolites: From Traditional Medicine to Modern Drug Discovery. Processes 2021, 9, 1344. https:// doi.org/10.3390/pr9081344

Academic Editor: Ioannis Nikolakakis

Received: 26 June 2021

Accepted: 29 July 2021

Published: 30 July 2021

Publisher's Note: MDPI stays neutral with regard to jurisdictional claims in published maps and institutional affiliations.

Copyright: (c) 2021 by the authors. Licensee MDPI, Basel, Switzerland. This article is an open access article distributed under the terms and conditions of the Creative Commons Attribution (CC BY) license (https:// creativecommons.org/licenses/by/ $4.0 /)$.

\begin{abstract}
Cancer incidence and mortality rate are growing worldwide. The effectiveness of cancer therapy depends on the degree of cancer development. Anticancer prevention, screening tests, detection of precancerous conditions or cancers at an early stage of development help to prevent the development of cancer, and in the event of cancer development, they provide the best chance for a full recovery. However, in most cases of advanced cancer, there is no method that can fully cure this disease. Recently, natural products have gained more attention in cancer therapy. Panax ginseng (PG), one of the most popular natural products, is reported to have a wide range of pharmacological activities in cancer. Therefore, the anti-cancer effects and mechanisms of PG and its metabolites (compound K, Ginsenoside Rh1, Rh2, Rh3 and F1) in five major cancers (lung cancer, breast cancer, colon cancer, prostate cancer and stomach cancer) are reviewed in this study. It is confirmed that PG and its metabolites regulated apoptosis, epithelial mesenchymal transition (EMT), angiogenesis, cell cycle arrest and multidrug resistance (MDR) in vitro and in vivo cancer models. In particular, ginsenoside Rh2 showed anticancer effects in all five major cancers. This review could improve the understanding of anticancer mechanisms of PG and its metabolites against major five cancers. Further clinical studies are needed for development anti-cancer drugs using PG and its metabolites.
\end{abstract}

Keywords: Panax ginseng; cancer; compound K; ginsenoside Rh2; apoptosis; angiogenesis; multidrug resistance

\section{Introduction}

Cancer is one of the leading causes of death in all countries around the world, and the incidence of cancer is increasing due to complex causes such as aging, growth of the population, changes in risk factors such as lifestyle changes and socioeconomic development [1]. Cancer mortality in developed countries is decreasing, while in developing countries, it tends to increase [2]. Advanced countries have a high prevalence of all cancers, but intermediate to underdeveloped countries show a high prevalence in lung, colorectal, breast and prostate cancer. This tendency is caused by increased early diagnosis and advances in treatment technology (only the mortality rate) in developed countries.

According to statistics of Global Cancer Statistics (GLOBOCAN), there were 18.1 million new cases, and 9.6 million death cases of cancer in 2018 alone. Among various cancers, lung cancer (11.6\% of the total cases), female breast cancer $(11.6 \%)$, colorectal cancer $(10.2 \%)$, prostate cancer $(7.1 \%)$ and stomach cancer $(5.7 \%)$ are among the top five with a high incidence. Symptoms of advanced cancer vary widely depending on age, gender and cancer 
area [3], however, the following ten symptoms are known to be most common: pain, easy fatigue, weakness, anorexia, lack of energy, dry mouth, constipation, early satiety, dyspnea and greater than $10 \%$ weight loss [4]. Cancer patients have a combination of these symptoms and, on average, experience eight or more symptoms during the onset period [5] and specific symptoms are associated with reduced survival [3]. In addition, cancer causes poor quality of life and extreme pain to patients. Studies suggest cancer screening could improve survival and reduce mortality of cancer [6,7].

Recently, studies showed that infection and inflammation have considerable relationship to cancer [8,9]. In 2008, infection accounted about 16\% (2 million) for 12.7 million new cancer cases that occurred worldwide [10]. Inflammation, in response to tissue injury such as by various infectious agents, activates leukocytes (neutrophils, monocytes and eosinophils) and various cytokines that may lead to chronic inflammation. Prolonged inflammatory mediators are closely related to neoplasia by inducing proneoplastic mutations, adaptive responses and resistance to apoptosis [11,12]. In the tumor microenvironment, inflammation stimulates carcinogenesis as well as environmental changes such as angiogenesis. Infectious agents such as Epstein-Barr virus, hepatitis B and C viruses, Kaposi sarcoma herpes virus, human immunodeficiency virus (HIV) type 1, human papillomaviruses, human T-cell lymphotropic virus type 1 and Helicobacter pylori are closely associated with the induction of cancer disease [8]. The above-mentioned factors lead to the development of neoplasms in tissues and organs sensitive to them. In addition, there is growing evidence that the inflammatory process itself can promote carcinogenesis by the interplay between autophagy and inflammasome activation in cancer [13]. Ghrelin is a hormone produced mainly in gastric mucosa that stimulates the release of pituitary growth hormone and increases appetite [14]. It is reported that ghrelin has anti-inflammatory and antioxidant activities by affecting theproliferation of cells $[14,15]$ as well protective and therapeutic effects in different parts of the body, including the heart [16], kidneys [17], oral cavity [18,19], stomach [15], duodenum [20], pancreas [21] and colon [22,23]. In addition, ghrelin administration suppresses inflammation-associated colorectal carcinogenesis in mice [24]. According to Shin et al., similar effects have been reported in the case of PG. PG attenuated the activation of cyclooxygenase-2 (COX-2) and inducible nitric oxide synthase (iNOS) with suppression of nuclear factor-kappa B (NF- $\mathrm{kB}$ ) and signal transducer and activation of transcription 3 (STAT3), exhibiting protective and anti-cancer effects in mouse models of colitis and carcinogenesis [25]. These data are evidence for the anti-cancer activity of Panax ginseng, as well as the possible mechanism of this effect.

To overcome this dreadful disease, research on cancer is actively ongoing, however, the mechanisms of cancer are still not fully understood. One of the mechanisms currently uncovered is cancer cells' avoidance of apoptosis, which is programmed cell death [26]. Apoptosis can be broadly divided into extrinsic and intrinsic pathways (Figure 1) [27].

The extrinsic pathway is induced by the activation of cell membrane tumor necrosis factor (TNF) receptors (e.g., CD95 (APO-1/Fas)), TNF-related apoptosis-inducing ligand (TRAIL) receptors by the CD95 ligand ((CD95-L), TRAIL). They trigger Fas-associated death domain (FADD) and Caspase-8, which cause apoptosis. On the other hand, the intrinsic pathway forms cytochrome c/Apoptotic protease activating factor-1(Apaf-1)/Caspase9-containing apoptosome complex through the release of apoptogenic factors (e.g., cytochrome c, apoptosis inducing factor (AIF), or Smac/DIABLO) in the mitochondrial intermembrane space. This activates Caspase- 9 and causes apoptosis. These two pathways can be interconnected by the Bcl-2 family, etc. In addition, cancer cells proliferate by advancing the cell cycle. The cell cycle is regulated by cyclin-dependent kinases (cdks) and their cyclin partners and, in particular, interruption of the Rb-E2F pathway is known to be associated with various tumors [28]. Targeting these mechanisms, various treatments are currently being developed. Surgery, chemotherapy, $\gamma$-irradiation, suicide gene therapy and immunotherapy, which have recently been used in clinical practice, have anti-cancer effects [29]. As mentioned above, cancer treatments have been developed, however, there is still the possibility of relapse or undesirable side effects such as acute and delayed 
nausea, mouth ulcerations, mild cognitive impairments and increased risk of developing other types of cancers [30]. Therefore, natural products for complementary uses are in the limelight and their possibility for cancer treatment is gaining more attention.

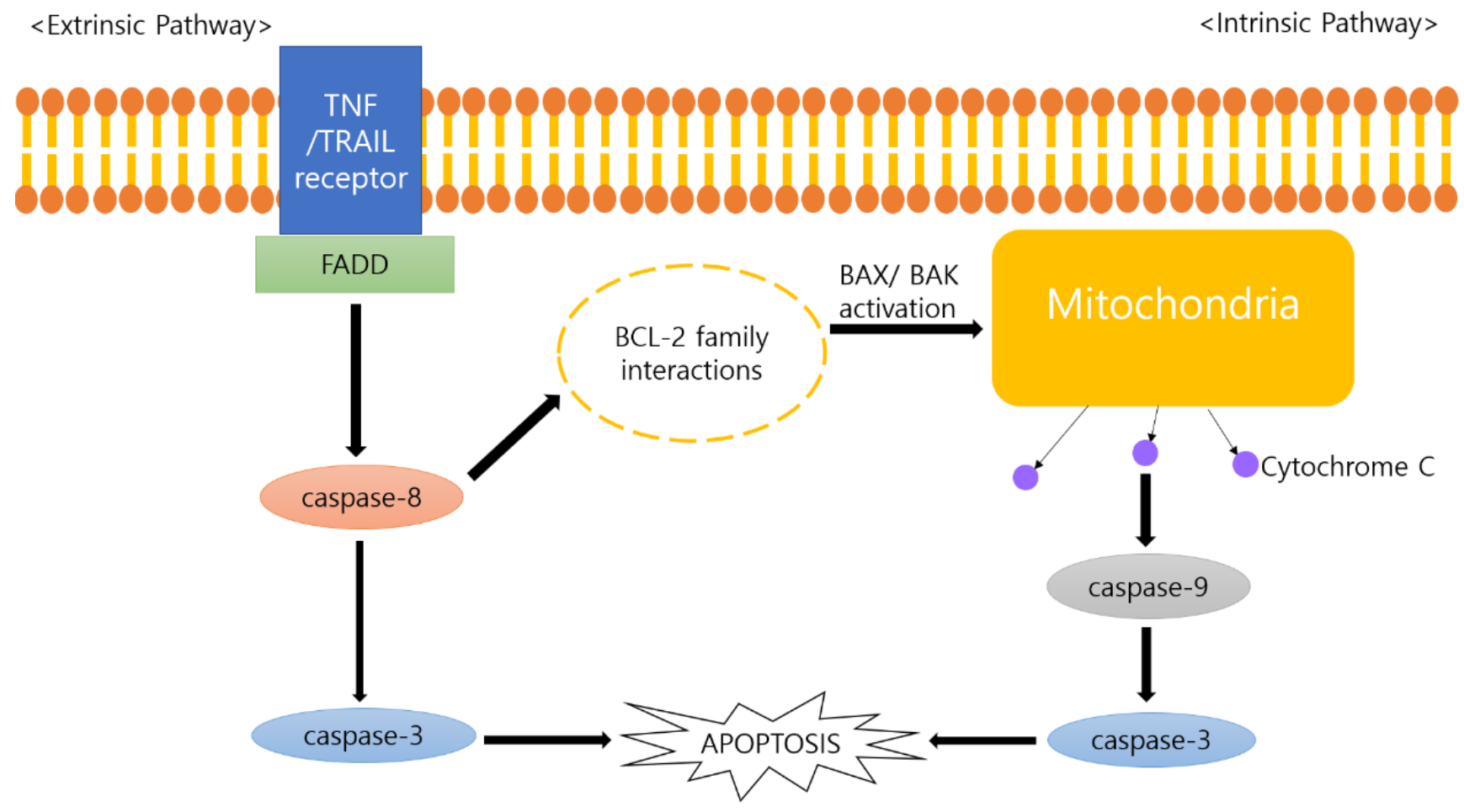

Figure 1. Schematic diagram of intrinsic and extrinsic apoptosis pathways. TNF, tumor necrosis factor; TRAIL, TNF-related apoptosis-inducing ligand; FADD, Fas-associated death domain; BCL-2, B-cell lymphoma 2; BAX, Bcl-2-associated X protein; BAK, Bcl-2 homologous antagonist killer.

Panax ginseng (PG), one of the most generally used herbal medicines in Asia, is reported to have a wide range of pharmacological activities [31,32]. Ginsenosides, also known as steroid-like saponins, are unique to ginseng species [33]. Ginsenosides have been widely proven to be effective in neurodegenerative diseases and cardiovascular diseases [34,35], and in the case of cancer, effect of treatment and prevention against breast, lung and colon cancer have been reported [36-38]. In particular, a clinical trial showed that ginsenoside improved quality of life after chemotherapy in epithelial uterine cancer [39]. Among many ginsenosides in PG, ginsenoside Rb1, Rb2, Rc, Rd, Re, Rf and Rg1 account for most of the ginsenosides [40]. Ginsenosides can be divided into protopanaxadiol (PPD) groups (ginsenosides Ra3, Rb1, Rc, Rd, Rg3 and Rh2) and protopanaxatriol (PPT) groups (ginsenosides Rg1, Re, Rh1 and R1) [41]. Although ginsenosides show various pharmacological effects, intact ginsenosides have extremely low oral bioavailability from the large intestine [42,43]. Without decomposition by gastric juices or liver enzymes, ginsenosides pass into the large intestine directly from the stomach and small intestine. By human fecal microflora, ginsenosides are metabolized and mostly converted to compound K. After oral administration, in the PPD group, ginsenoside Rb1, Rb2, Rb3, Rc and Rd are transformed into compound $\mathrm{K}$ by most bacteria, such as Bacteroides sp., Bifidobacterium sp., Eubacterium sp. and Fusobacterium sp. [44,45]. Ginsenoside Rg1 and Re belonging to the PPT group are metabolized into ginsenoside F1 and Rh1 by Bacteroides sp., Bifidobacterium sp., Eubacterium sp. and Fusobacterium sp. Ginsenoside Rg3 is converted into Rh2 by intestinal bacteria such as Bacteroides sp., Bifidobacterium sp. and Eubacterium sp. (Figure 2).

Recent studies have reported the metabolization of ginsenosides in oral administration and the antitumor effects of ginsenoside metabolites. However, there has been no research to summarize the effects of PG on each individual cancer. In this study, the anticancer effect 
of PG, its mechanism and its metabolites (compound K, Ginsenoside Rh1, Rh2, Rh3 and F1) are reviewed.
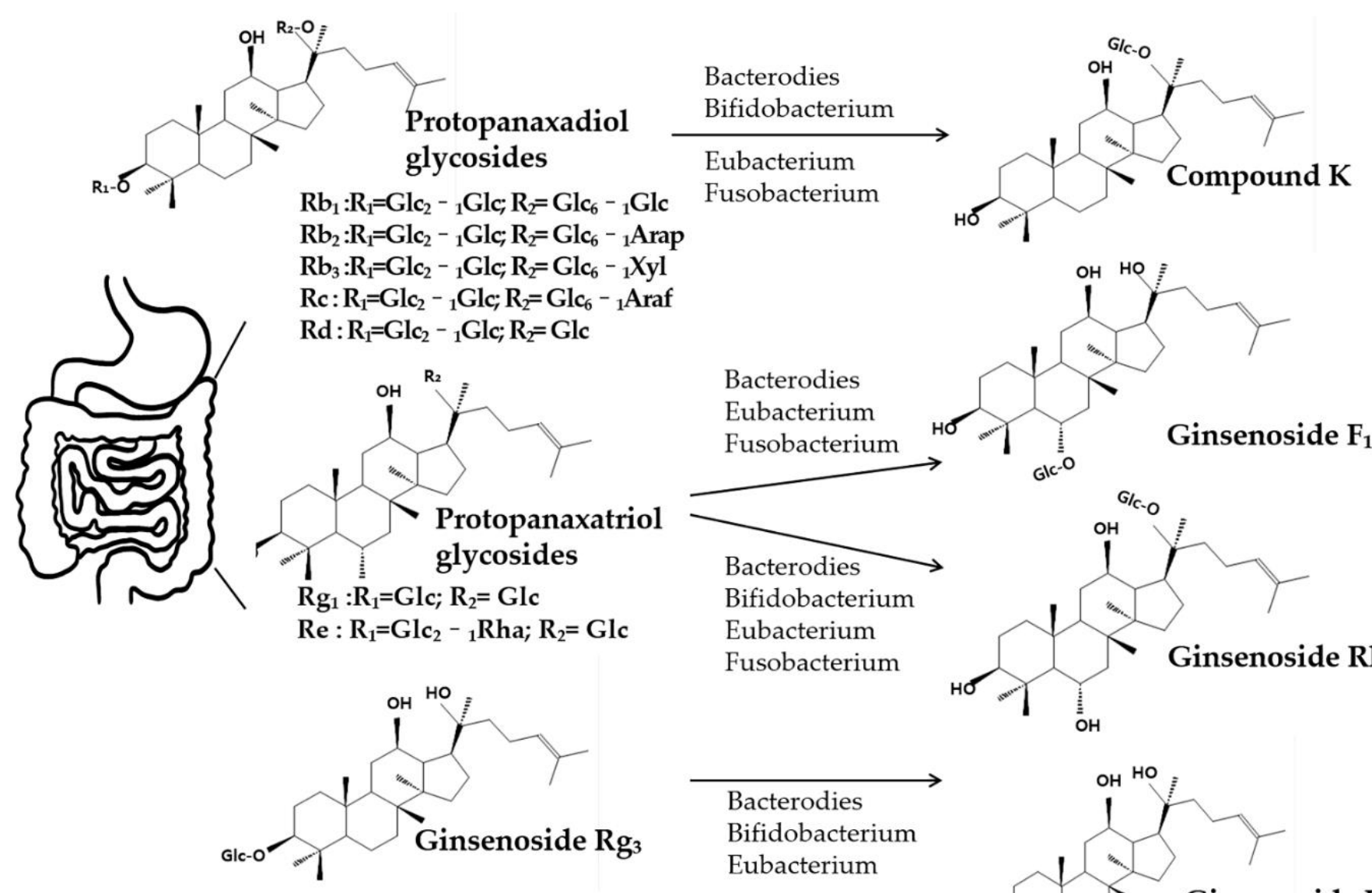

Eubacterium

Fusobacterium

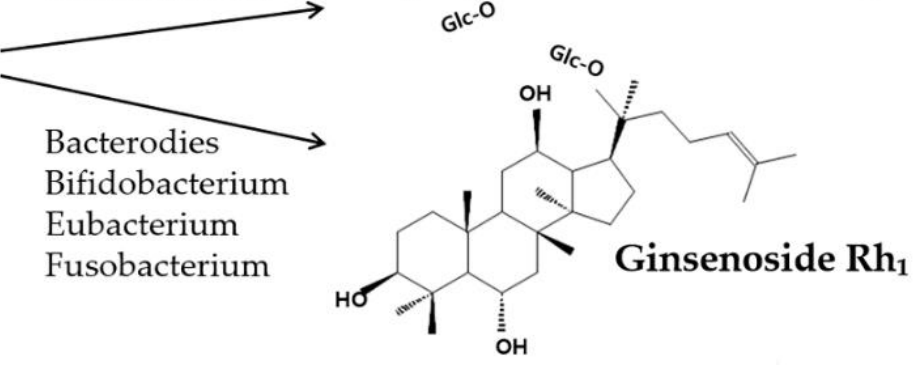

\section{Bacterodies \\ Bifidobacterium \\ Eubacterium}

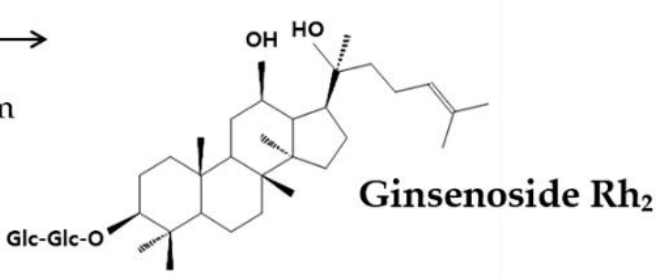

Figure 2. Schematic diagram of the pathway of PG and its metabolites. Ginsenosides are deglycosylated to compound K, ginsenoside F1, Rh1 and Rh2 by intestinal bacteria such as Bacteroides, Bifidobacterium, Eubacterium and Fusobacterium. Glc, $\beta$-D-glucopyranosyl; Arap, $\alpha$-L-arabinopyranosyl; Xyl, $\beta$-D-xylopyranosyl; Araf, $\alpha$-L-arabinofuranosyl.

\section{Methods}

In order to review the anticancer effects of ginseng and its metabolites, related articles were searched for in Pubmed and Google Scholar. Five major cancers including lung cancer, breast cancer, colon cancer, prostate cancer, stomach cancer, and "Panax ginseng extract" or PG metabolites, such as "compound K", "ginsenoside Rh1", "ginsenoside Rh2", "ginsenoside Rh3", "ginsenoside F1" were used as keywords. Studies on fermented red ginseng extract were included, but studies on the synergistic effects of PG with other drugs were excluded. Eighty-one papers were excluded according to the criteria, resulting in 41 remaining. Then, data was classified into sub-categories followed by types of ginsenosides to each cancer.

\section{Results}

\subsection{Anti-Cancer Effect of PG and Its Metabolites on Lung Cancer}

Lung cancer accounts for the leading incidence rate (11.6\%) and mortality rate (18.4\%) [1]. Even with early diagnosis and treatment, the prognosis is very poor as the mortality rate within 5 years is 19\% (non-small cell lung cancer and small cell lung cancer combined). The five-year survival rate is higher for non-small cell lung cancer (23\%) than small cell lung cancer $(6 \%)$ [46]. Twelve studies have been reported on the effects of Panax ginseng and its metabolites against lung cancer (Table 1). 
Table 1. Panax ginseng and its metabolites against lung cancer.

\begin{tabular}{|c|c|c|c|c|c|}
\hline Compound/Extract & Cell Line/Animal Model & Dose; Duration & Efficacy & Mechanism & Reference \\
\hline \multicolumn{6}{|l|}{ In vitro } \\
\hline Korean Red Ginseng Extract & A549, H1264, H1299, Calu-6 & $400 \mu \mathrm{g} / \mathrm{mL} ; 48 \mathrm{~h}$ & Induction of cancer cell apoptosis & $\uparrow \mathrm{AIF}$ & [47] \\
\hline Modified Red Ginseng Extract & A549 & $100 \mu \mathrm{g} / \mathrm{mL} ; 25,50,72 \mathrm{~h}$ & $\begin{array}{l}\text { Inhibition of cancer cell growth } \\
\text { Induction of autophagy }\end{array}$ & $\begin{array}{l}\uparrow \text { LC3, Beclin-1, ATG5, p-Akt } \\
\qquad \text { mTOR, 4EBP1 }\end{array}$ & [48] \\
\hline Modified Red Ginseng Extract & A549 & $25,50 \mu \mathrm{g} / \mathrm{mL} ; 24 \mathrm{~h}$ & Induction of cancer cell apoptosis & $\begin{array}{c}\uparrow \text { Bax, Caspase-3 } \\
\downarrow \text { Bcl-2, PARP, p-ERK, Caveolin-1, } \\
\text { FAK1, FN }\end{array}$ & [49] \\
\hline Butanol-extracted Mountain Ginseng & A549, NCI-H358, NCI-H596 & $0.08,0.4,2,10 \mathrm{mg} / \mathrm{mL} ; 48 \mathrm{~h}$ & $\begin{array}{l}\text { Induction of cancer cell apoptosis } \\
\text { Inhibition of cancer cell proliferation }\end{array}$ & $\uparrow$ Caspase- 3 , Caspase- 8 & [50] \\
\hline CK, CK-M & A549 & $12.15 \mu \mathrm{g} / \mathrm{mL} ; 24 \mathrm{~h}$ & $\begin{array}{l}\text { Induction of apoptosis } \\
\text { Inhibition of tumor growth }\end{array}$ & $\uparrow$ Caspase-9, Caspase-3, PARP & [53] \\
\hline CK, CK-M & A549, PC-9 & $20 \mu \mathrm{g} / \mathrm{mL} ; 24 \mathrm{~h}$ & $\begin{array}{l}\text { Induction of apoptosis } \\
\text { Inhibition of tumor cell invasion, metastasis, and efflux }\end{array}$ & $\begin{array}{l}\uparrow \text { Bax, Bcl-2, MMP-2, Caspase-3, } \\
\text { p-glycoprotein }\end{array}$ & [54] \\
\hline G-Rh2 & A549, H1299 & $60,100 \mu \mathrm{M} ; 24 \mathrm{~h}$ & $\begin{array}{l}\text { Induction of macrophage differentiation } \\
\text { Prevention of cancer cell migration }\end{array}$ & $\downarrow$ VEFG-C, MMP2, MMP9 & [55] \\
\hline G-Rh2 & H1229 & $10,20,30,40,50 \mu \mathrm{M} / \mathrm{L} ; 24 \mathrm{~h}$ & $\begin{array}{c}\text { Inhibition of cancer proliferation } \\
\text { Induction of ROS meditated ER stress dependent apoptosis }\end{array}$ & $\uparrow$ ATF4, CHOP, Caspase-4 & [56] \\
\hline pseudo-G-Rh2 & A549 & $24,48,96 \mu \mathrm{M} ; 24 \mathrm{~h}$ & $\begin{array}{l}\text { Inhibition of cell proliferation } \\
\text { Induction of mitochondria-associated apoptosis } \\
\text { Induction of ROS production }\end{array}$ & $\begin{array}{c}\uparrow \text { mitochondrial cytochrome c, } \\
\text { Caspase-9, Bax, PARP, p-Raf, Ras, p53 } \\
\downarrow \text { Bcl-2 }\end{array}$ & [57] \\
\hline \multicolumn{6}{|l|}{ In vivo } \\
\hline G-Rh2 & $\begin{array}{l}\text { C57BL } / 6 \text { mice } \\
(\mathrm{n}=14)\end{array}$ & $\begin{array}{l}40 \mathrm{mg} / \mathrm{kg} / \text { day; } \\
21 \text { days }\end{array}$ & $\begin{array}{l}\text { Induction of macrophage differentiation } \\
\text { Prevention of cancer cell migration } \\
\text { Reduction of tumor size }\end{array}$ & $\downarrow$ VEGF-C, CD206 & [55] \\
\hline G-Rh2 & $\begin{array}{l}\text { BALB/c nu/nu nude mice } \\
\qquad(\mathrm{n}=10)\end{array}$ & $\begin{array}{l}20 \mathrm{mg} / \mathrm{kg} / \text { day, } \\
40 \text { days }\end{array}$ & Reduction of tumor volume & $\uparrow$ ATF4, CHOP, Caspase-4 & [56] \\
\hline \multicolumn{6}{|l|}{ Clinical trial } \\
\hline Fermented Red Ginseng Extract & Non-small cell lung cancer patients & $3000 \mathrm{mg} ; 60$ days & $\begin{array}{l}\text { Improvement of FSI score, CM symptom score, psychological and } \\
\text { physical } \\
\text { conditions, QOL } \\
\text { Inhibition of chemotherapy } \\
\text { toxicity }\end{array}$ & & [51] \\
\hline $\begin{array}{l}\text { AIF, apoptosis-inducing fact } \\
\text { protein; Bcl-2, B-cell lymphon } \\
\text { Rk1, Rg3, Rg5; FOXO3, forkh } \\
\text { ginsenoside-Rh2; VEFG-C, v } \\
\text { pseudo-G-Rh2, pseudo-ginse }\end{array}$ & $\begin{array}{l}\text { C3, light chain 3; ATG5, autoph } \\
\text { PARP, poly ADP ribose polym } \\
\text { ox O3; FasL, fas ligand; CK, co1 } \\
\text { lar endothelial growth factor C } \\
\text { de-Rh2. }\end{array}$ & $\begin{array}{l}\text { d 5; p-Akt, phospho-pr } \\
\text { K, phospho-extracellu } \\
\text { CK-M, compound K-l } \\
\text { natrix metalloproteina }\end{array}$ & $\begin{array}{l}\text { ase B; mTOR, mammalian target of rapamycin; } 4 \mathrm{EBP} 1,4 \\
\text {-regulated kinase; FAK1, focal adhesion kinase } 1 \text {; FN, fibr } \\
\text { xed micelles; p53, tumor protein 53; p21, tumor protein } 21 \\
4 \text {, activating transcription factor 4; CHOP, CCAAT/enh }\end{array}$ & $\begin{array}{l}\text { nding protein 1; Bax, BCL2-associ } \\
\text { ctin; KG-135, formulation of ginse } \\
\text { AP-2, matrix metalloproteinase-2; } \\
\text { er-binding protein homologous } p\end{array}$ & $\begin{array}{l}\text { ed X } \\
\text { side } \\
\text { Rh2, } \\
\text { tein; }\end{array}$ \\
\hline
\end{tabular}


PG extracted through different solvents showed anti-tumor effects on lung cancer. Yu et al. fractioned PG water extract (PGWE) into four types: hexane (HX), dichloromethane (MC), ethyl acetate (EA), butanol (BuOH)-soluble [47]. Among them, the EA fraction of PGWE revealed apoptotic cell death in four types of human lung carcinoma cells, A549, H1264, H1299 and Calu-6. It was used at the concentration of $400 \mu \mathrm{g} / \mathrm{mL}$ for $48 \mathrm{~h}$. Yoo et al. also reported that saponin-enzyme-treated PG water extract at $100 \mu \mathrm{g} / \mathrm{mL}$ for 25 , 50 and $72 \mathrm{~h}$ exerted inhibition of cancer cell growth and autophagy on A549 cells [48]. It down-regulated mTOR, 4EBP1 and up-regulated LC3, Beclin-1, ATG-5 and p-Akt. Hwang also used enzyme-modified PG extract which was fractioned via water, methanol and butanol and applied to A549 [49]. It was treated at 25 and $50 \mu \mathrm{g} / \mathrm{mL}$ for a day. Finally, it caused induction of apoptosis through increases in Bax and Caspase- 3 and decreases in Bcl-2, PARP, p-ERK, Vabeolin-1, FAK1 and FN. Additionally, Lee et al. reported that Butanol-extracted mountain ginseng revealed induction of apoptosis and inhibition of cell proliferation by increasing Caspase-3,8 [50]. Furthermore, Jiang et al. conducted a clinical trial that investigated the effects of fermented red ginseng extract on non-small cell lung cancer patients treated with chemotherapy [51]. When administered with $3000 \mathrm{mg}$ for 60 days, the experimental group showed improvement in FSI score, CM symptom score, psychological and physical conditions and quality of life (QOL). Additionally, the treatment inhibited chemotherapy toxicity.

Compound $\mathrm{K}(\mathrm{CK})$ is also expected to be a potential treatment for lung cancer. $\mathrm{Li}$ et al. reported that CK treatment $(20 \mu \mathrm{M}$ for 18,24 , and $72 \mathrm{~h})$ on H1299, H460 and A549 induced sensitization of cisplatin by increasing levels of p21 and p53 [52]. When CK was encapsulated in phosphatidylcholine and phosphoethanolamine polyethylene mixed micelles, it exerted significant induction of apoptosis and inhibition of tumor growth [53]. It increased Caspase-9, 3 and PARP at a concentration of $12.15 \mu \mathrm{g} / \mathrm{mL}$ for a day in A549. There was another study by Yang et al. that treated mixed-micelles with $\mathrm{CK}$ at $20 \mu \mathrm{M}$ for $24 \mathrm{~h}$ in the same cell line [54]. They observed induction of apoptosis and inhibition of metastasis by increasing Bax, Bcl-2, MMP-2, Caspase-3 and p-glycoprotein. The following two studies suggested that CK mixed micelles improve antitumor efficacy by enhancing permeability, solubility and retention.

G-Rh2 treatment also produced anti-tumor effects in lung cancer. Li et al. revealed that G-Rh2 treatment at 60 and $100 \mu \mathrm{M}$ for a day inhibited cell migration and induced macrophage differentiation dose-dependently [55]. Moreover, they found the same result through in vivo experiments, where C57BL/ 6 mice injected murine Lewis lung carcinoma cells subcutaneously. G-Rh2 showed the reduction of tumor size by decreasing VEGF-C and CD 206. Ge et al. reported that G-Rh2 inhibited cell proliferation and induced ER stress dependent apoptosis in the same cell line, H1229 [56]. It started to show significant effect at $30 \mu \mathrm{M}$ for $24 \mathrm{~h}$ by increasing the level of ATF4, CHOP and Caspase- 4 . They also observed reduction of tumor volume in vivo experiments in nude mice. Additionally, pseudo-G-Rh2 had a much greater anti-lung cancer effect, especially by apoptosis. Wang et al. identified suppression of cell proliferation and induction of mitochondria-associated apoptosis when it is treated at the concentrations of 24,48 and $96 \mu \mathrm{M}$ for $24 \mathrm{~h}$ in A549. It also induced ROS production and led to apoptosis via the Ras/Raf/ERK/p53 pathway. It up-regulated mitochondrial cytochrome c, Caspase-9, Bax, PARP, p-Raf, Ras and p53 and down-regulated Bcl-2. These findings provide strong evidence that G-Rh2 may also function as a potent anticancer drug in lung cancer treatment.

\subsection{Anti-Cancer Effect of PG and Its Metabolites on Breast Cancer}

Female breast cancer is one of the types of cancer with the highest incidence in the world. Around 2.1 million female breast cancer cases were newly diagnosed and approximately 627,000 deaths were reported, ranked as the first leading cause of cancer death in the females in 2018 [1]. Extracts of PG and its metabolites were reported in 11 studies for their anti-cancer effect in breast cancer (Table 2). Antitumor effects of PG and its 
metabolites were studied without comparison with other anticancer agents. There were no significant side reactions or toxicity of PG and its metabolites reported.

Song et al. showed the inhibition of MDA-MB-231 cancer cell lines growth by 12.5, 25, 50 and $100 \mu \mathrm{M}$ of ginsenoside Rh2- MIX (G-Rh2-MIX) for $24 \mathrm{~h}$. G-Rh2-MIX, comprised of 20(S)-Rh2, 20(R)-Rh2, Rk2 and Rh3 as a 10-g unit was a new combination of enzymatic conversions using Viscoenzyme $\mathrm{L}$ and acid-heat treatment [58]. Viscozyme L treatment transformed the major ginsenosides $\mathrm{Rb} 1, \mathrm{Rb} 2$, $\mathrm{Rc}$ and $\mathrm{Rd}$ into ginsenoside $\mathrm{F} 2$, followed by acid treatment transforming ginsenoside F2 into G-Rh2-MIX. Interestingly, only 20(R)$\mathrm{Rh} 2$ did not showed anticancer activity on MDA-MB -231 and other cancer cell lines in the components of Rh2-MIX. Kwak et al. reported that $2.5 \mu \mathrm{M}$ of PPD exerted antitumor effects by induction of apoptosis for 24 days in triple negative breast cancer MDAMB- 231 cells [59]. PPD treatment stimulated Caspase-dependent apoptosis in breast cancer cells via up-regulation of c-Caspase-8, -3, c-PARP and down-regulation of fulllength $\mathrm{BH} 3$ Interacting domain death agonist (BID) and poly adenosine diphosphate-ribose polymerase (PARP). Extracts from PG contain several components such as ginsenosides, polysaccharides and peptides. Ginsenosides are categorized into protopanaxadiol (PPD), protopanaxatriol (PPT) and oleanane saponins [60]. Red ginseng extract (RGE) and its component ginsenoside Rg3 (G-Rg3), which is markedly increased through the steaming process, has been reported to have anti-tumor activity. Oh et al. reported that RGE treatment reduced the cell viability of breast cancer cell line MCF-7 at doses of 0.5, 1, 2 and $5 \mathrm{mg} / \mathrm{mL}$ for $48 \mathrm{~h} \mathrm{[61].} \mathrm{In} \mathrm{addition,} \mathrm{fermented} \mathrm{RGE,} \mathrm{treated} \mathrm{with} \mathrm{microbial} \mathrm{strain}$ (Lactobacillus rhamnousus KCTC 5003), contained remarkably higher levels of Rg3 and more effectively reduced cancer cell viability compared with nonfermented RGE (nf-RGE). Additionally, RGE and G-Rg3 showed suppression of manifestation and regulation of selfrenewal activation of stem-like breast cancer cells MCF-7 and MDA-MB-231. RGE treatment ( $1 \mathrm{mg} / \mathrm{mL}$ for 5 days) and G-Rg3 treatment at a dose of $25 \mu \mathrm{M}$ for 5 days reduced the expression of hypoxia inducible factor- $1 \alpha$ (HIF-1 $\alpha$ ), phosphorylated Akt (p-Akt), SRY-box transcription factor 2 (Sox-2) and B cell-specific Moloney murine leukemia virus integration site 1 (Bmi-1) resulting in reduction of the populations of CD44 high/ CD24 low in MDAMB-231 cells [62]. Compound $\mathrm{K}$ (CK) is an intestinal bacterial metabolite of the ginsenosides $\mathrm{Rb} 1, \mathrm{Rb} 2$, and $\mathrm{Rc}$ from Bacteroides JY-6 that showed anticancer activity. Kwak et al. revealed that $\mathrm{CK}$ treatment induced programmed necrosis in MCF-7 via regulation of the glycogen synthase kinase $3 \beta$ (GSK3 $\beta$ ) signaling pathway, resulting in a decrease in p-GSK3 $\beta$, $\beta$ catenin and cyclin D1 at doses of 10,30,50 and $70 \mu \mathrm{M}$ for $24 \mathrm{~h}$ [63]. In addition, the study showed the increased expression of PARP-1, which is cleaved by Caspase during apoptosis, suggesting that CK did not induce apoptosis and autophagy. However, Zhang et al. reported that CK at a dose of $50 \mu \mathrm{M}$ for $24,48,72$ and $96 \mathrm{~h}$ combined with cisplatin inhibited the epithelial mesenchymal transition (EMT) and induced the apoptosis in MCF-7 breast cancer cell by up-regulation of $\mathrm{C}$-cadherin and down-regulation of $\mathrm{N}$-cadherin, vimentin, fibronectin (FN) and p-Akt [64]. G-Rh2 (ginsenoside Rh2) was proven to have the anticancer activity against MCF-7 cells through epigenetically regulated immune pathway in terms of genome-wide deoxyribonucleic acid (DNA) methylation changes [65]. Treatment of 20 and $50 \mu \mathrm{M} \mathrm{G}-\mathrm{Rh} 2$ for $24 \mathrm{~h}$ up-regulated the clathrin interactor 1 (CLINT), ST3 BetaGalactoside Alpha-2,3-Sialyltransferase 4 (ST3GAL4), Chromosome 1 open reading frame 198 (C1orf198) expression through hyper-methylation and down-regulated the expression of Caspase-1, Insulin Like 5 (INSL5), Olfactory Receptor family 52 Subfamily A member 1 (OR52A1). Additionally, $50 \mu \mathrm{M}$ of G-Rh2 treatment induced both early and late apoptosis with complete inhibition of cell growth, while $20 \mu \mathrm{M}$ treatment slightly suppressed the cell proliferation. According to Hou et al., $20 \mu \mathrm{g} / \mathrm{mL}$ of G-Rh2 treatment for $24 \mathrm{~h}$ ameliorated the doxorubicin-induced senescence bystander effect between normal epithelial MCF$10 \mathrm{~A}$ cells and breast carcinoma MDA-MB-231 cells [66]. Reciprocal effects of senescent breast tumor and normal cells under stimulation with a clinical dose of doxorubicin through senescence-associated secretory phenotype (SASP) were efficiently attenuated by G-Rh2 through down-regulation of phosphor mitogen-activated protein kinase kinase 1 
(p-MEK1), phosphor-p38 mitogen-activated protein kinase (p-p38MAPK), phosphor signal transducer and activator of transcription 3 (p-Stat3), phosphor-nuclear factor kappa-lightchain-enhancer of activated B cells p 65(p-NF- $\mathrm{kB}$ p65), interleukin-6 (IL-6), interleukin-8 (IL-8) and the mRNA level of monocyte chemoattractant protein 1 (MCP-1), C-X-C motif Chemokine Ligand 1 (CXCL1). Zhang et al. showed that G-Rh2 treatment at doses of $0.625,1.25,2.5,5,10,20,40$ and $80 \mu \mathrm{mol} / \mathrm{L}$ for 24,48 and $72 \mathrm{~h}$ effectively inhibited cell proliferation of MCF-7 and MCF-7/ADM cell lines [67]. Significant activation of Caspase-3 was detected in the adriamycin-resistant human mammary carcinoma (MCF-7/ADM) cell line after G-Rh2 treatment with $40 \mu \mathrm{mol} / \mathrm{L}$, but not in MCF-7 cell lines. Additionally, G-Rh2 treatment at doses of 5, 10, 20 and $40 \mu \mathrm{mol} / \mathrm{L}$ for $72 \mathrm{~h}$ notably decreased ADM IC 50 of MCF-7 / ADM cell lines which suggests reversal of multidrug resistance. Ren et al. also reported the synergistic effect of G-Rh2 combined with biochanin A on MDA-MB-231 and MCF-7 human breast cancer cells [68]. G-Rh2 treatment mixed with biochanin A at doses of 30, 35, 40, 45, 50, 55, 60 and $70 \mu \mathrm{M}$ for $72 \mathrm{~h}$ improved the inhibition of cell migration, proliferation, and invasion by up-regulation of p-p58, p-p28 and p-ASK1 and down-regulation of TRAF2. Xu Wen et al. reported that G-Rh2 treatment at doses of 10, 20, $40,60,80$ and $100 \mu \mathrm{M}$ for $24 \mathrm{~h}$ exerted anti-tumor effects on breast cancer by upregulation of miRNA-29a, -222 and downregulation of miRNA-34a [69]. When G-Rh2 treatment was applied to MCF-7, MCF-7 with $100 \mathrm{nM}$ of Docetaxel (MCF-7/Doc, docetaxel-resistant MCF-7 cells) and MCF-7 with $500 \mathrm{nM}$ of Adriamycin (MCF-7/ Adr, adriamycin-resistant MCF-7 cells), it caused a strong anti-chemoresistance effect in BCA cells through regulation of three specified drug-resistant microRNAs (miRNAs).

Table 2. Panax ginseng and its metabolites against breast cancer.

\begin{tabular}{|c|c|c|c|c|c|}
\hline Compound/Extract & $\begin{array}{c}\text { Cell Line/Animal } \\
\text { Model }\end{array}$ & Dose; Duration & Efficacy & Mechanism & Reference \\
\hline \multicolumn{6}{|l|}{ In vitro } \\
\hline G-Rh2-MIX & MDA-MB-231 & $\begin{array}{c}12.5,25,50,100 \\
\mu \mathrm{M} ; 24 \mathrm{~h}\end{array}$ & $\begin{array}{l}\text { Inhibition of growth of } \\
\text { cancer cells }\end{array}$ & & [58] \\
\hline Protopanaxadiol & MDA-MB-231 & $2.5 \mu \mathrm{M} ; 24 \mathrm{~h}$ & Induction of apoptosis & $\begin{array}{c}\uparrow \text { c-Caspase- } 8,-3, \\
\text { c-PARP } \\
\downarrow \text { BID }\end{array}$ & [59] \\
\hline $\begin{array}{c}\text { Fermented-red } \\
\text { ginseng water } \\
\text { extract }\end{array}$ & MCF-7 & $\begin{array}{c}0.5,1,2,5 \mathrm{mg} / \mathrm{mL} ; \\
48 \mathrm{~h}\end{array}$ & $\begin{array}{c}\text { Inhibition of } \\
\text { proliferation and } \\
\text { viability }\end{array}$ & & [61] \\
\hline $\begin{array}{l}\text { Red ginseng } \\
\text { extract, } \\
\text { G-Rg3 }\end{array}$ & $\begin{array}{c}\text { MCF-7, } \\
\text { MDA-MB-231, }\end{array}$ & $\begin{array}{c}1 \mathrm{mg} / \mathrm{mL} ; 5 \text { days } \\
25 \text { MM; } 5 \text { days }\end{array}$ & $\begin{array}{l}\text { Suppression of } \\
\text { manifestation } \\
\text { Inhibition of } \\
\text { self-renewal }\end{array}$ & $\begin{array}{l}\downarrow \text { HIF-1 } \alpha, \text { p-Akt, } \\
\text { Sox-2, Bmi-1, }\end{array}$ & {$[62]$} \\
\hline CK & MCF-7 & $\begin{array}{c}10,30,50,70 \mu \mathrm{M} ; \\
24,48 \mathrm{~h}\end{array}$ & $\begin{array}{c}\text { Induction of } \\
\text { programmed necrosis }\end{array}$ & $\begin{array}{c}\uparrow \mathrm{GSK} 3 \beta \\
\downarrow \beta \text {-catenin, cyclin } \\
\text { D1 }\end{array}$ & [63] \\
\hline CK & MCF-7 & $\begin{array}{c}50 \mu \mathrm{M} ; 24,48,72 \\
96 \mathrm{~h}\end{array}$ & $\begin{array}{c}\text { Inhibition of } \\
\text { proliferation and EMT } \\
\text { Induction of apoptosis }\end{array}$ & $\begin{array}{l}\uparrow C \text {-cadherin } \\
\downarrow N \text {-cadherin, } \\
\text { vimentin, FN, } \\
\text { p-Akt }\end{array}$ & {$[64]$} \\
\hline G-Rh2 & MCF-7 & $20,50 \mu \mathrm{M} ; 24 \mathrm{~h}$ & Induction of apoptosis & $\begin{array}{c}\uparrow \text { CLINT, } \\
\text { ST3GAL4, } \\
\text { C1orf198 } \\
\downarrow \text { Caspase-1, } \\
\text { INSL5, OR52A1 }\end{array}$ & [65] \\
\hline
\end{tabular}


Table 2. Cont

\begin{tabular}{|c|c|c|c|c|c|}
\hline Compound/Extract & $\begin{array}{c}\text { Cell Line/Animal } \\
\text { Model }\end{array}$ & Dose; Duration & Efficacy & Mechanism & Reference \\
\hline G-Rh2 & MDA-MB-231 & $20 \mu \mathrm{g} / \mathrm{mL} ; 48 \mathrm{~h}$ & $\begin{array}{c}\text { Amelioration of } \\
\text { doxorubicin-induced } \\
\text { SASP }\end{array}$ & $\begin{array}{c}\downarrow \text { p-MEK1, } \\
\text { p-p38MAPK, } \\
\text { p-Stat3, p-NF-кB } \\
\text { p65, IL-6, -8, } \\
\text { MCP-1, CXCL1 }\end{array}$ & {$[66]$} \\
\hline G-Rh2 & $\begin{array}{c}\text { MCF-7 } \\
\text { MCF-7/ADM }\end{array}$ & $\begin{array}{c}\text { (1) } 0.625,1.25,5,10 \\
20,40,80 \mu \mathrm{mol} / \mathrm{L} ; \\
24,48,72 \mathrm{~h} \\
\text { (2) } 5,10,20,40 \\
\mu \mathrm{mol} / \mathrm{L} ; 72 \mathrm{~h}\end{array}$ & $\begin{array}{l}\text { (1) Induction of } \\
\text { apoptosis } \\
\text { (2) Reversal of MDR }\end{array}$ & (1) $\uparrow$ c-Caspase-3 & {$[67]$} \\
\hline G-Rh2 & $\begin{array}{c}\text { MCF-7 } \\
\text { MDA-MB-231 }\end{array}$ & $\begin{array}{c}30,35,40,45,50 \\
55,60,70 \mu \mathrm{M} ; 72 \mathrm{~h}\end{array}$ & $\begin{array}{l}\text { Inhibition of } \\
\text { proliferation, invasion }\end{array}$ & $\begin{array}{c}\uparrow \mathrm{p}-\mathrm{p} 53, \mathrm{p}-\mathrm{p} 38 \\
\mathrm{p}-\mathrm{ASK} 1 \\
\downarrow \text { TRAF2 }\end{array}$ & [68] \\
\hline G-Rh2 & $\begin{array}{c}\mathrm{MCF}-7, \\
\mathrm{MCF}-7 / \mathrm{Doc} \\
\mathrm{MCF}-7 / \mathrm{Adr}\end{array}$ & $\begin{array}{c}10,20,40,60,80 \\
100 \mu \mathrm{M} ; 24 \mathrm{~h}\end{array}$ & $\begin{array}{l}\text { Reduction of drug } \\
\text { resistance }\end{array}$ & $\begin{array}{c}\uparrow \operatorname{miR}-29 \mathrm{a},-222, \\
\text { Bax } \\
\downarrow \text { miR-34a }\end{array}$ & [69] \\
\hline
\end{tabular}

G-Rh2-MIX, ginsenoside Rh2 mix comprised of 20(S)-Rh2, 20(R)-Rh2 and Rh3 as a 10-g unit; PPD, protopanaxadiol; c-Caspase-8, cleavageCaspase-8; c-PARP, cleaved poly adenosine diphosphate-ribose; BID, BH3 interacting domain death agonist; RGE, red ginseng extract; G-Rg3, ginsenoside Rg3; HIF-1 $\alpha$, hypoxia inducible factor-1 $\alpha$; p-Akt, phosphorylated Akt; Sox-2, SRY-box transcription factor 2; Bmi-1, B cell-specific Moloney murine leukemia virus integration site 1 ; CK, compound K; p-GSK3 $\beta$, phospho-glycogen synthase kinase $3 \beta$; EMT, epithelial mesenchymal transition; FN, fibronectin; G-Rh2, ginsenoside Rh2; CLINT, clathrin interactor 1; ST3GAL4, ST3 beta-galactoside Alpha-2,3-Sialyltransferase 4; C1orf198, chromosome 1 open reading frame 198; INSL5, insulin like 5; OR52A1, olfactory receptor family 52 subfamily A member 1; SASP, senescence associated secretory phenotype; p-MEK1, phosphor mitogen activated protein kinase kinase 1; p-p38MAPK, phosphor-p38 mitogen-activated protein kinase; p-Stat3, phosphorylated signal transducer and activator of transcription 3; p-NF-кB p65, phosphorylated nuclear factor kappa-light-chain-enhancer of activated B cells p 65; IL-6, interleukin-6; IL-8, interleukin8; MCF-7/ADM, Adriamycin-resistant human mammary carcinoma; MDR, multidrug resistance; p-p53, phosphorylated p53; p-p38, phosphorylated p38; p-ASK1, phosphorylated apoptosis signal-regulating kinase; TRAF2, tumor necrosis factor receptor associated factor; MCF-7/Doc, docetaxel-resistant MCF-7 cells; MCF-7/Adr, Adriamycin-resistant MCF-7 cells; miR, microRNA.

\subsection{Anti-Cancer Effect of PG and Its Metabolites on Colon Cancer}

Colon cancer is the third most common malignancy and fourth most common cause of cancer mortality worldwide [1]. Colon cancer is also the second most common cause of cancer-related deaths in the United States and other developed countries, despite important advances in detection, surgery and chemotherapy [70]. Several studies have reported anticolon cancer effects of PG (Table 3).

PG root water extract showed anti-tumor effects on colon cancer. Kim et al. reported that PG root water-extracted treatment at doses of 1 and $2 \mathrm{mg} / \mathrm{mL}$ for 24 and $72 \mathrm{~h}$ induced the repression of hypoxia-induced EMT on colon cancer HT29 and HCT116 cells by downregulation of NF- $\mathrm{kB}, \mathrm{ERK} 1 / 2$, Snail, Slug, Twist, $\alpha \mathrm{V} \beta 6$ integrin and E-cadherin [71]. Li et al. revealed that when PG root water-extracted treatment was applied to HT-29 colon cancer cells with 50, 100 and $200 \mu \mathrm{g} / \mathrm{mL}$ for 24,48 and $72 \mathrm{~h}$, it caused the inhibition of cell proliferation, induction of cell cycle arrest and cell apoptosis cells through downregulation of CDK2, CDK4, CDK6, TOP1, MYC, MDM2 and CCND1 and upregulation of BAX, CDNK2B, Caspase-8, -3 and TP53 [72]. These two results suggest that efficacy varies with concentration in HT29, where low concentrations of PG water extract suppress EMT and high concentrations regulate the cell cycle. Additionally, Kee et al. reported that PG root ethanol extract showed inhibition of the EMT process and induction of apoptosis and cell cycle arrest on CT26 by downregulation E-cadherin, N-cadherin, vimentin, Snail, MMP-2 and MMP-9 [73]. Both HT29, a tissue of colorectal adenocarcinoma in Homo sapiens and CT26, a tissue of colorectal carcinoma in Mus musculus, showed an effect on inhibition of EMT. These three results suggest that PG extract is involved hypoxia-induced EMT and cell cycle arrest, which can be effective on colon cancer. Yao et al. reported that CK treatment at doses of 40,50,60 and $70 \mu \mathrm{M}$ for $48 \mathrm{~h}$ on HCT116 induced cell cycle arrest in the G1 phase and apoptosis. It decreased levels of p21, p53, Bax CDK6, cyclin E, Bcl2. They 
additionally found that CK showed anti-inflammatory effects on HT29 [74]. Additionally, compound K exerted significant anti-inflammatory effects even at low concentrations (40, 60 and $80 \mu \mathrm{M}$ ) and for a short time (6 and $12 \mathrm{~h}$ ), only in HT 29, by reducing IL-8. There are two main linked pathways in apoptosis, which are the extrinsic, or death receptor, pathway and the intrinsic, or mitochondrial, pathway [75]. The following two studies suggested that CK-induced apoptosis worked on both pathways. Proteolytic cleavage of PARP and release of cytochrome $\mathrm{c}$ was observed by Tischlerova et al. upon CK treatment at a dose of $40 \mu \mathrm{M}$ for 24,48 and $72 \mathrm{~h}$ in HCT116. It increased Caspase-3, $-9, \mathrm{Bcl}-2$ and p-p38 MAPK and reduced p-ERK 1/2, p-Akt, NF- $k B$ p50, NF- $k B$ p65 and p-BAD [76]. In the same cell line, TRAIL-induced apoptosis was detected upon CK treatment $(25,50 \mu \mathrm{M}$; $48 \mathrm{~h}$ ) by Chen et al. [77]. It facilitated c-Caspase- $8,-9,-3$, Bax, tBid, cytochrome c, DR5 and $\mathrm{CHOP}$ and inhibited Mcl-1, Bcl-2, XIAP and cFLIP. These findings demonstrate that CK has anti-colon cancer effects, especially by induction of cell apoptosis through both pathways. G-Rh2 treatment also induced anti-tumor effects on colon cancer. Yang et al. revealed that G-Rh2 treatment with 5, 15, 25 and $50 \mu \mathrm{M}$ over 3,6 and $12 \mathrm{~h}$ inhibited cancer cell proliferation. Suppression of p-EKR2, p-Histone H3, p- ERK1/2, and p-p90RSK were observed in HCT116 [78]. Zhu et al. showed arrest in the G1 phase, promotion of apoptosis and induction of ROS depletion and autophagy in the same cell line. Treatment with $12.5 \mu \mathrm{M}$ over $24 \mathrm{~h}$ increased the level of Bax/Bcl2 and Caspase-3 [79]. Interestingly, 20 (S)$\mathrm{G}-\mathrm{Rh} 2$ especially has much more anti-colon cancer effect. Han et al. identified suppression of CRC invasion and tumor metastasis when treated 20 (S)-G-Rh2 (1, 3, 5, 7 and $10 \mu \mathrm{M}$; $0.5,1$ and $3 \mathrm{~h}$ ) in the same cell line, HCT116. Decrease of pY-STAT3, p-JAK2, MMP-1, MMP-2 and MMP-9 were observed [80]. Additionally, in SW620, colon cells derived from metastatic site of lymph node, tumor metastasis was observed with following treatment of 20(S)- G-Rh2. Liu et al. observed that G-Rh2 treatment at doses of 5, 10 and $20 \mu \mathrm{M}$ for $24 \mathrm{~h}$ decreased the migration and EMT processes, proliferation and promoted apoptosis. This effect was especially shown in HCT8, ileocecal colorectal adenocarcinoma, by upregulating cleaved-Caspase 3, p-IKB, MRP1, MDR1, LRP and GST and down-regulating cyclin D1, CDK2, p-Rb, Bcl-2 [81]. Additionally, Ma et al. reported that LoVo, derived from a metastatic site of the left supraclavicular region showed inhibition of cell proliferation and promotion of apoptosis when treated with $250 \mu \mathrm{g} / \mathrm{mL} \mathrm{G}-\mathrm{Rh} 2$ over $24 \mathrm{~h}$. It elevated Smad4, Bax, and Caspase-3 and decreased P-gp, Bcl-2 [82]. Furthermore, G-Rh2 showed an identical effect on LoVo/L-OHP cells and oxaliplatin (L-OHP)-resistant colon cancer cells. These findings provide strong evidence that G-Rh2 may also function as a potent anticancer drug for drug resistance in colon cancer treatment.

Table 3. Panax ginseng and its metabolites against colon cancer.

\begin{tabular}{|c|c|c|c|c|c|}
\hline Compound/Extract & $\begin{array}{c}\text { Cell Line/Animal } \\
\text { Model }\end{array}$ & Dose; Duration & Efficacy & Mechanism & Reference \\
\hline \multicolumn{6}{|l|}{ In vitro } \\
\hline $\begin{array}{l}\text { Panax Ginseng root } \\
\text { water extract }\end{array}$ & НСТ116, НT29 & $1,2 \mathrm{mg} / \mathrm{mL} ; 24,72 \mathrm{~h}$ & $\begin{array}{c}\text { Repression of } \\
\text { hypoxia-induced EMT }\end{array}$ & $\begin{array}{c}\downarrow \text { NF-kB, ERK1/2, } \\
\text { Snail, Slug, Twist, } \\
\alpha \mathrm{V} \beta 6 \text { integrin, } \\
\text { E-cadherin }\end{array}$ & [71] \\
\hline $\begin{array}{l}\text { Panax Ginseng root } \\
\text { water extract }\end{array}$ & HT29 & $\begin{array}{c}50,100,200 \mu \mathrm{g} / \mathrm{mL} ; \\
24,48,72 \mathrm{~h}\end{array}$ & $\begin{array}{c}\text { Inhibition of cell } \\
\text { proliferation, } \\
\text { Induction of cell cycle } \\
\text { arrest and cell } \\
\text { apoptosis }\end{array}$ & $\begin{array}{c}\text { 个 BAX, CDNK2B, } \\
\text { Caspase-8, -3, } \\
\text { TP53, Bax, } \\
\text { p21WAF1, } \\
\text { p27Kip1, c-Myc, } \\
\text { p15INK4b, p53 } \\
\downarrow \text { CDK2, CDK4, } \\
\text { CDK6, TOP1, } \\
\text { MYC, MDM2, } \\
\text { CCND1, Cdk2, } \\
\text { CDK4 }\end{array}$ & [72] \\
\hline
\end{tabular}


Table 3. Cont.

\begin{tabular}{ccccc}
\hline Compound/Extract & $\begin{array}{c}\text { Cell Line/Animal } \\
\text { Model }\end{array}$ & Dose; Duration & Efficacy & Mechanism \\
\hline $\begin{array}{c}\text { Panax Ginseng root } \\
\text { ethanol extract }\end{array}$ & CT26 & $0.5,1 \mathrm{mg} / \mathrm{mL} ; 24 \mathrm{~h}$ & $\begin{array}{c}\text { Inhibition of EMT } \\
\text { process } \\
\text { Induction of apoptosis } \\
\text { and cell } \\
\text { cycle arrest }\end{array}$ & $\begin{array}{c}\downarrow \text { E-cadherin, } \\
\text { N-cadherin, } \\
\text { Vimentin, Snail, } \\
\text { MMP-2, MMP-9 }\end{array}$ \\
\hline
\end{tabular}

(1) Arrest in the G1

(1) $40,50,60,70 \mu \mathrm{M}$;

CK

HCT116, HT29

(2) 40, 60, $80 \mu \mathrm{M}$; 6, $12 \mathrm{~h}$

CK

HCT116

$40 \mu \mathrm{M} ; 24,48,72 \mathrm{~h}$ PARP phase,

(1) $\uparrow$ p21, p53, Bax

Induction of cell apoptosis,

(2) Inhibition of inflammation $\downarrow$ CDK6, cyclin E,

$\mathrm{Bcl} 2$

(2) $\downarrow$ IL-8
[74]

Proteolytic cleavage of

Release of cytochrome

$\uparrow$ Caspase-3, -9,

Bcl-2, p-p38 MAPK

$\downarrow$ p-ERK $1 / 2$,

$\begin{array}{cc}\text { Induction of } & \text { p-Akt, NF- } \mathrm{kB} \text { p50, } \\ \text { NF- } & \text { NFase-dependent } 65, \mathrm{p}-\mathrm{BAD}\end{array}$

Caspase-dependent apoptosis apoptosis
Induction of

TRAIL-induced

\section{$\uparrow$ c-Caspase-8, -9,}

-3 , Bax, tBid,

CK HCT116, HT29 25, $50 \mu \mathrm{M} ; 48 \mathrm{~h}$ cytochrome c, DR5,

$\mathrm{CHOP}$

$\downarrow \mathrm{Mcl}-1, \mathrm{Bcl}-2$,

XIAP, cFLIP

\begin{tabular}{|c|c|c|c|c|c|}
\hline G-Rh2 & $\begin{array}{c}\text { LoVo, } \\
\text { LoVo/L-OHP }\end{array}$ & $250 \mu \mathrm{g} / \mathrm{mL} ; 24 \mathrm{~h}$ & $\begin{array}{c}\text { Inhibition of cell } \\
\text { proliferation. } \\
\text { Promotion of } \\
\text { apoptosis and changes } \\
\text { in drug resistance } \\
\text { genes }\end{array}$ & $\begin{array}{l}\uparrow \text { Smad4, Bax, } \\
\text { Caspase-3. } \\
\downarrow \text { p-gp, Bcl-2 }\end{array}$ & [82] \\
\hline G-Rh2 & HCT8, LoVo & $5,10,20 \mu \mathrm{M} ; 24 \mathrm{~h}$ & $\begin{array}{l}\text { Inhibition of migration } \\
\text { and EMT process, } \\
\text { proliferation. } \\
\text { promotion of } \\
\text { apoptosis }\end{array}$ & $\begin{array}{c}\uparrow \text { c-Caspase-3, } \\
\text { p-IkB, MRP1, } \\
\text { MDR1, LRP, GST } \\
\downarrow \text { cyclin D1, CDK2, } \\
\text { p-Rb, Bcl-2 }\end{array}$ & [81] \\
\hline G-Rh2 & HCT116 & $\begin{array}{c}5,15,25,50 \mu \mathrm{M} ; \\
3,6,12 \mathrm{~h}\end{array}$ & $\begin{array}{l}\text { Inhibition of cancer } \\
\text { cell proliferation }\end{array}$ & $\begin{array}{c}\uparrow \mathrm{p} \text {-EKR2, } \\
\text { p-Histone H3, p- } \\
\text { ERK1/2, p-p90RSK }\end{array}$ & [78] \\
\hline $\begin{array}{l}\text { 20(S)- } \\
\text { G- Rh2 }\end{array}$ & HCT116, SW620 & $\begin{array}{c}1,3,5,7,10 \mu \mathrm{M} ; 0.5 \\
1,3 \mathrm{~h}\end{array}$ & $\begin{array}{c}\text { Suppression of cancer } \\
\text { invasion and tumor } \\
\text { metastasis }\end{array}$ & $\begin{array}{c}\downarrow \text { pY-STAT3, } \\
\text { p-JAK2, MMP-1, } \\
\text { MMP-2, MMP-9 }\end{array}$ & [80] \\
\hline G- Rh2 & HCT116 & $12.5 \mu \mathrm{M} ; 24 \mathrm{~h}$ & $\begin{array}{c}\text { Arrest in the G1 phase } \\
\text { Promotion of } \\
\text { apoptosis } \\
\text { Induction of ROS } \\
\text { depletion and } \\
\text { autophagy }\end{array}$ & $\begin{array}{l}\uparrow \mathrm{Bax} / \mathrm{Bcl} 2, \\
\text { Caspase-3 }\end{array}$ & [79] \\
\hline
\end{tabular}

EMT, epithelial mesenchymal transition; NF-kB, nuclear factor kappa B; ERK, extracellular-signal-regulated kinase; BAX, BCL2 Associated X; TP53, Tumour protein p53; CDK, Cyclin-dependent kinases; TOP1, DNA topoisomerases 1; MDM2, Mouse double minute 2 homolog; CCND1, Cyclin D1; MMP, Matrix metallopeptidases; CK, compound K; IL-8, Interleukin-8; MAPK, mitogen-activated protein kinase; p-BAD, phosphor-Bcl-2-antagonist of cell death protein; tBid, truncated Bid; DR5, Death receptor 5; CHOP, cyclophosphamide, doxorubicin, vincristine, and prednisone; XIAP, X-linked inhibitor of apoptosis protein; TRAIL, TNF-related apoptosis-inducing ligand; cFLIP, cellular FLICE-like inhibitory protein; G-Rh2, Ginsenoside Rh2; MRP1, Multidrug resistance-associated protein 1; MDR1, multidrug resistance mutation 1; STAT3, Signal transducer and activator of transcription 3; p-JAK2, phospho-Janus kinase 2; ROS, reactive oxygen species. 


\subsection{Anti-Cancer Effect of PG and Its Metabolites on Prostate Cancer}

Prostate cancer is the third most diagnosed cancer (7.1\%) [1]. The metastasis of cancer can be easily achieved on bones and lymph nodes in prostate cancer. Four studies have shown that ginsenoside $\mathrm{Rh} 2$ has an anti-cancer effect against prostate cancer (Table 4).

Table 4. Panax ginseng and its metabolites against prostate cancer.

\begin{tabular}{|c|c|c|c|c|c|}
\hline Compound/Extract & $\begin{array}{c}\text { Cell Line/Animal } \\
\text { Model }\end{array}$ & Dose; Duration & Efficacy & Mechanism & Reference \\
\hline \multicolumn{6}{|l|}{ In vitro } \\
\hline G-Rh2 & PC3, DU145 & $\begin{array}{c}0.01,0.1,1 \mathrm{mg} / \mathrm{mL} \\
24,48,96 \mathrm{~h}\end{array}$ & $\begin{array}{l}\text { Inhibition of } \\
\text { proliferation }\end{array}$ & $\downarrow$ CDKN1A & [83] \\
\hline G-Rh2 & PC3, DU145 & $\begin{array}{c}0.05,0.075,0.1 \mathrm{mM} \\
24 \mathrm{~h}\end{array}$ & $\begin{array}{l}\text { Induction of } \\
\text { apoptosis }\end{array}$ & $\begin{array}{l}\uparrow \text { PPAR- } \delta \\
\downarrow \text { p-STAT3 }\end{array}$ & {$[84]$} \\
\hline \multicolumn{6}{|l|}{ In vivo } \\
\hline G-Rh2 & $\begin{array}{l}\text { LNCaP, PC3, } \\
\text { DU145/nude mice }\end{array}$ & $\begin{array}{c}0,100,500,1000 \\
5000,10,000 \\
\mathrm{mg} / \mathrm{kg} ; 32 \text { days }\end{array}$ & $\begin{array}{l}\text { Inhibition of } \\
\text { angiogenesis }\end{array}$ & $\downarrow$ CNNM1 & [85] \\
\hline G-Rh2 & $\begin{array}{l}\text { (1) nude mice } \\
\text { (2) PC3 }\end{array}$ & $\begin{array}{c}\text { (1) } 1 \mathrm{mg} / \mathrm{kg} ; 4 \\
\text { weeks } \\
\text { (2) } 0.1 \mathrm{mg} / \mathrm{mL} ; 2,4 \\
7 \text { days }\end{array}$ & $\begin{array}{c}\text { Inhibition of } \\
\text { proliferation and } \\
\text { invasion }\end{array}$ & $\begin{array}{c}\uparrow \text { TGF } \beta \text { receptor, } \\
\text { p-SMAD2, } \\
\text { CyclinD1, } \\
\text { CyclinB1, MMP2, } \\
\text { MMP9 } \\
\downarrow \text { p27 }\end{array}$ & [86] \\
\hline
\end{tabular}

G-Rh2, ginsenoside Rh2; CDKN1A, cyclin dependent kinase inhibitor 1A; PPAR- $\delta$, peroxisome proliferator-activated receptor delta; p-STAT3, phospho-signal transducer and activator of transcription 3; CNNM1, cyclin and CBS domain divalent metal cation transport mediator 1; TGF $\beta$, transforming growth factor beta; p-SMAD2, phospho-mothers against decapentaplegic homolog 2; MMP2, matrix metalloproteinase 2; MMP9, matrix metalloproteinase 9.

Gao et al. described that G-Rh2 inhibited the prostate cancer cells by inhibition of proliferation [83]. PC3 and DU145 cells were exposed to $0.01,0.1$ and $1 \mathrm{mg} / \mathrm{mL}$ of G-Rh2 and cell proliferation was inhibited in a dose dependent manner. G-Rh2 dose-dependently decreased the cyclin dependent kinase ionhibitor 1A (CDKN1A) protein but not mRNA in prostate cancer cells. This suggests that G-Rh2 can control CDKN1A protein translation which is mediated with microRNA. Additionally, the researchers found that microRNA4295 was the only microRNA regulated by G-Rh2 among CDKN1A targeting miRNA. G-Rh2 may inhibit the proliferation of prostate cancer cells by suppressing microRNA-4295 that facilitates CDKN1A. Tong et al. also reported that G-Rh2 induced apoptosis in prostate cancer cells [84]. DU145, PC3 prostate cell lines and human prostate stromal WPMY-1 cells were incubated with $0.05,0.075$ and $0.1 \mathrm{mM}$ of G-Rh2 for $24 \mathrm{~h}$. The results showed that G-Rh2 reduced the cell viability of DU145 and PC3 in a concentration-dependent manner. However, the cell viability of WPMY-1 was less affected by G-Rh2 treatment. The G-Rh2 inhibited the prostate cancer cells by up-regulation of peroxisome proliferator-activated receptor delta (PPAR- $\delta$ ) and that can lead ROS and superoxide induction and phosphosignal transducer and activator of transcription 3 (p-STAT3) down-regulation. Huang et al. reported that ginsenoside Rh2 (G-Rh2) inhibited the angiogenesis by targeting and suppressing cyclin and CBS domain divalent metal cation transport mediator 1 (CNNM1) [85]. Prostate cancer cells such as LNCaP, PC3 and DU145 were transplanted in nude mice and $\mathrm{Rh} 2$ was treated at $0,100,500,1000,5000$ and $10,000 \mathrm{mg} / \mathrm{kg}$ for 32 days. The tumor mass volume was measured at $8,12,16,20,24,28$ and 32 days. The researchers observed that G-Rh2 significantly inhibited the growth of prostate cancer cell lines in mice compared to no treatment by inhibition of CD31, VEGR, PDGF and CNNM1 in prostate cells. Zhan et al. also studied the efficacy of G-Rh2 against prostate cancer growth in vivo and in vitro [86]. $\mathrm{G}-\mathrm{Rh} 2$ was injected in veins of nude mice at a concentration of $1 \mathrm{mg} / \mathrm{kg}$ for twice per week for 4 weeks, but the control group was injected same volume of saline injection. After 
4 weeks, mice were examined for tumor growth and the treatment with G-Rh2 resulted the inhibition of cell growth significantly. In vitro, G-Rh2 inhibited the proliferation and invasion of prostate cancer cell line, PC3. The researchers detected the activation of TGF- $\beta$ receptor which regulated the p27 and matrix metalloproteinases (MMPs).

\subsection{Anti-Cancer Effect of PG and Its Metabolites on Gastric Cancer}

Gastric cancer is one of the leading causes of death (8.2\%) in 2018 [1]. 1.03 million people newly developed gastric cancer, and 780,000 people died by gastric cancer. There are two studies showing that PG and its metabolites are effective in gastric cancer (Table 5).

Table 5. Panax ginseng and its metabolites against gastric cancer.

\begin{tabular}{|c|c|c|c|c|c|}
\hline Compound/Extract & $\begin{array}{c}\text { Cell Line/Animal } \\
\text { Model }\end{array}$ & Dose; Duration & Efficacy & Mechanism & Reference \\
\hline \multicolumn{6}{|l|}{ In vitro } \\
\hline $\begin{array}{l}\text { Enzymatically } \\
\text { fortified ginseng } \\
\text { extract (FGX) }\end{array}$ & KATO3 & $\begin{array}{c}31.25,62.5,125 \\
\mu \mathrm{g} / \mathrm{mL} ; 24 \mathrm{~h}\end{array}$ & $\begin{array}{c}\text { Inhibition of } \\
\text { proliferation } \\
\text { Induction of apoptosis }\end{array}$ & $\begin{array}{c}\uparrow \text { Bax, IкB } \alpha \\
\downarrow \text { p-mTOR, p-PKB }\end{array}$ & [87] \\
\hline G-Rh2 & SGC-7901 & $\begin{array}{c}5,10,20 \mu \mathrm{g} / \mathrm{mL} \\
24,48 \mathrm{~h}\end{array}$ & $\begin{array}{c}\text { Inhibition of } \\
\text { proliferation } \\
\text { Induction of cell cycle } \\
\text { arrest and apoptosis }\end{array}$ & $\begin{array}{c}\uparrow \mathrm{Bax} \\
\downarrow \mathrm{Bcl}-2\end{array}$ & [88] \\
\hline
\end{tabular}

Bax, Bcl-2-associated X protein; IкB $\alpha$, nuclear factor of kappa light polypeptide gene enhancer in B-cells inhibitor, alpha; mTOR, mammalian target of rapamycin; PKB, protein kinase B; G-Rh2, ginsenoside Rh2; Bcl-2, B-cell lymphoma 2.

Enzymatically fortified PG extract and G-Rh2 showed anti-gastric cancer effects. Hwang et al. compared the effects of a ginseng butanolic extract (GBX) and enzymatically fortified ginseng extract (FGX) on gastric cancer cell line KATO3 [87]. The treatment of GBX $(31.25,62.5$ and $125 \mu \mathrm{g} / \mathrm{mL})$ for $24 \mathrm{~h}$ did not affect KATO3 cells but FGX inhibited cell proliferation in the same condition depending on its concentration. Additionally, the study shows the population of apoptotic KATO3 cells was increased after FGX treatment. FGX up-regulated the expression of Bcl-2-associated X protein (Bax) and nuclear factor of kappa light polypeptide gene enhancer in B-cells inhibitor, alpha (IкB $\alpha$ ) proteolysis and blocked the phosphorylation of mammalian target of rapamycin (mTOR) and protein kinase $B$ (PKB). Qian et al. reported that G-Rh2 inhibited proliferation and induced apoptosis of human gastric cancer SGC-7901 cells [88]. In several experiments under different conditions with G-Rh2 $(5,10$ and $20 \mu \mathrm{g} / \mathrm{mL} ; 24$ and $48 \mathrm{~h})$, it exerted the anti-tumor effects in G-Rh2 by inhibition of gastric cancer side population cells (SP cells) proliferation and induction of cell cycle arrest and cell apoptosis. In the cell cycle of SP cells, the percentage of G0/G1 cells was increased and S/G2/M cells were decreased. The results show that G-Rh2 arrested the G0/G1 phase cells. The experiments also showed that G-Rh2 induced the activity of pro-apoptotic protein Bax and inhibited anti-apoptotic protein B-cell lymphoma 2 (Bcl-2) depend on its dose and duration.

\section{Discussion}

Cancer is one of the serious causes of death around the world, with lung cancer, female breast cancer, prostate cancer, colorectal cancer, and stomach cancer accounting for the top five incidences $[1,89]$. Panax ginseng (PG), one of the most popular herbal medicines has been reported to have notable pharmacological anti-cancer activities with its various ginsenosides. In 2000, there was a review study about the cancer prevention potential of PG in animal experiments and in epidemiological studies. PG could be cancer-preventive however, there was insufficient evidence [90]. Furthermore, there was no systematic review of the anti-cancer treatment effects of PG extract and its metabolites against top five cancers. In this study, PG extracts and metabolites of ginsenosides in PG with antitumor effect against the top five cancers were reviewed for the first time. Although it is necessary, since 
it is the metabolites that act in the body, there has been no review classifying effects of each metabolite. PG is usually absorbed by oral administration, however, oral bioavailability of ginsenosides is generally low due to their low membrane permeability [42]. For G-Rh1, the absorption rate in rats is less than $1 \%$ and most ginsenosides except compound $\mathrm{K}$ are absorbed at rates less than 5\% [91]. This study can help discover effective drugs and provide the basis for future attempts to increase bioavailability.

\subsection{Overview of Anti-Cancer Studies of Panax ginseng and Its Metabolites on Major 5 Cancers}

In the last 5 years, 41 studies reported that Panax ginseng and its metabolites showed anticancer effects on five major cancers, most of which were in vitro studies, and a few were in vivo or clinical trials. There were no reports of them causing cancer. Rather, there was no evidence of toxicity and tumorigenicity according to the experiments that PG was injected up to $5000 \mathrm{mg} / \mathrm{kg}$ in Fischer 344 rats and B6C3F1 mice [92]. These studies support that PG is not genotoxic. However, there is a case report about the drug interactions of PG and Imatinib, inducing hepatotoxicity in chronic myelogenous leukemia patients [93]. There is also a study showing that PG could induce drug reaction with eosinophilia and systemic symptoms syndrome (DRESS) because of drug interaction with [94]. Therefore, because of the possibility of side effects and drug interaction problems, PG should be carefully taken according to the prescription of experts.

There were 11 studies about lung cancer, which includes eight in vitro studies, two in vitro and in vivo studies and one clinical trial. Five of them reviewed the effect of PG extract and three used CK. The others were about G-Rh2. Among them, Red ginseng water extract revealed its effect at very high concentrations, $400 \mu \mathrm{g} / \mathrm{mL}$ [47]. As for PG, each researcher used various solvent; water, hexane, dichloromethane, ethyl acetate, butanol and methanol and the same A549 cells. They confirmed the efficacy of induction of cell apoptosis, autophagy and inhibition of cell proliferation. In the case of CK, the anticancer effect was confirmed through the same A549 cells, and there were two studies using CK encapsulated in micelles. Research about G-Rh2 revealed inhibition of cell proliferation and induction of apoptosis via many different pathways in A439 and H1299 cells. Based on the above studies, PG and its metabolites have mainly shown the ability to cause apoptosis in lung cancer.

In the case of breast cancer, 13 in vitro studies were selected of which one tested a mixture of ginsenoside Rh2 and Rh3, one a mixture of protopanaxadiol, two an extract of red ginseng, two CKs, and five ginsenoside Rh2. In the case of red ginseng extract, the effect showed on high dose and duration of 1,2 and $5 \mathrm{mg} / \mathrm{mL} ; 48 \mathrm{~h}$ or $1 \mathrm{mg} / \mathrm{mL} ; 5$ days. Two studies used compound K and the MCF-7 cell line but showed contrary results. Dose and duration of studies were $50 \mathrm{uM} ; 48 \mathrm{~h}$, but programmed necrosis differed by apoptosis. Further studies are needed to clarify whether CK induces apoptosis and autophagy on MCF-7. In the case of ginsenoside Rh2, the anticancer effect was testified in MCF-7 and MDA-MB-231 cell lines by inducing apoptosis and reversing multi-drug resistance. Studies which used docetaxel-resistant MCF-7 and adriamycin-resistant MCF-7 confirmed the reducing effect of drug resistance.

As for colon cancer, this study identified 11 in vitro studies, which three tested PG root water/ethanol extracts, three tested CKs, and four G-Rh2. One study showed the effect at high concentration of $250 \mu \mathrm{g} / \mathrm{mL}$, requiring further study [82]. In the case of PG root water extract, the same HT29 cells were used, and the effects were inhibition of the cell cycle, EMT and proliferation, and induction of apoptosis. In the case of CK, the anticancer effect was confirmed through the same HCT 116 cells. In the case of G-Rh2, LoVo cells inhibited cell proliferation, EMT and induced apoptosis and MRD changes. HCT-116 cells showed similar effects by inhibiting metastasis, G1 stage arrest, and inducing apoptosis.

There were four studies about PG and its metabolites against prostate cancer. Only the G-Rh2 metabolite was tested on prostate cancer, and it was effective in inhibition of angiogenesis, proliferation, invasion and induction of apoptosis. However, most of the research was conducted at a high concentration of over $60 \mu \mathrm{g} / \mathrm{mL}$. 
There were two articles about PG and its metabolites against gastric cancer. Enzymatically fortified ginseng extract had efficacies of inhibition of proliferation and induction of apoptosis, the G-Rh2 also had the same efficacies and furthermore it induced cell cycle arrest. Unfortunately, research of PG's efficacy in gastric cancer has fewer findings compared to other cancers. Of the two articles reviewed, one used a high concentration in the cell experiments, making it difficult for its efficacy to be determined.

\subsection{Anti-Cancer Mechanisms of Panax ginseng and Its Metabolites}

The anticancer effect of PG has been shown to focus on the major anticancer mechanisms of general natural products reported in previous studies [95], not only that, but also encompassing all of these mechanisms. The effects of PG and its metabolites can be largely seen in three aspects. First, the most reported anti-cancer effects of these drugs appear to be through 'tumor growth inhibition'. For the five major cancers, there was a common effect, inhibiting cell proliferation and inducing apoptosis when treated with PG extract (PGE), ginsenoside G-Rh2 (G-Rh2), and compound K (CK). They mainly caused intrinsic apoptosis through the regulation of Bcl-2, Bax and activation of Caspase-9. In a few experiments, they exerted apoptosis induction through STAT3, NF-kB, MAPK, and Akt signaling pathways. Moreover, especially for colon cancer, PGE, G-Rh1 and CK induced cell cycle arrest in the G1 phase and so did G-Rh2 for gastric cancer. Next, they exhibited anticancer effects by inhibiting tumor progression. For colon cancer, PGE, G-Rh1 and CK repressed EMT, and so did CK for breast cancer. Additionally, G-Rh2 inhibited angiogenesis in prostate cancer. Tumor epithelial cells acquire stem features in the process of accumulating invasive behavior, which causes clinical difficulties [96]. In other words, EMT occupies a very important position in treatment resistance and cancer recurrence. Since the EMT inhibitory effect of PG is achieved by more than one target, it is expected to be able to respond more complexly and effectively to the heterogeneous properties of cancer. Finally, they showed anticancer effect through MDR (multi-drug resistance) reversal. G-Rh2 involved in reduction of MDR in breast cancer and colon cancer, and CK also showed sensitization of cisplatin. This result strongly supports existing studies that natural products can be effective in diminishing MDR by reducing the drug outflow by binding to the active sites of the membrane transporter [97]. It suggests that ginsenoside metabolites can be used not only as anti-cancer drugs, but as effective MDR modulators. The mechanisms and key factors were elucidated in Figure 3.

\subsection{Anti-Cancer Effects of Ginsenoside Rh2}

Among the metabolites of PG, G-Rh2 showed anticancer effects in the five major cancers. In particular, G-Rh2 in colorectal cancer showed multifunctional effects such as tumor growth inhibition through cell proliferation, apoptosis, and G1 phase arrest, metastasis suppression through EMT inhibition, and MDR reduction. In this way, G-Rh2 is considered a very potential component. Therefore, it is worth further study to address the limited utilization of G-Rh2 due to its low oral absorption and low bioavailability [98]. To increase bioavailability and improve pharmacological properties, chemical structure modification should be considered. This study indicated that PGE in lung cancer and G-Rh2 in colon cancer caused autophagy. Autophagy is closely related to apoptosis and can cause cell death, however, it promotes survival at low concentration and dies only at high concentrations [92]. Moreover, induction of autophagy process inhibits growth in some cancer cells, however, some cancer cells have been reported to have increased resistance to chemotherapy through induction of autophagy genes [99]. Thus, further studies are needed to utilize this part clinically.

\subsection{Anti-Cancer Effects of Compound $K$}

There were contradictory results that CK caused both apoptosis and necrosis in breast cancer. Unlike apoptosis, necrosis occurs when cells cannot tolerate metabolic or therapeutic stress [100]. In both experiments, CK was treated in the same cell line MCF-7 for 
the same dose and duration, $50 \mu \mathrm{M}$ for 24 and $48 \mathrm{~h}$. Thus, further experiment is necessary to determine whether $\mathrm{CK}$ is toxic enough to cause therapeutic stress, or necrosis occurred due to problems in experimental process that caused the cell to undergo stress other than a control factor, CK.

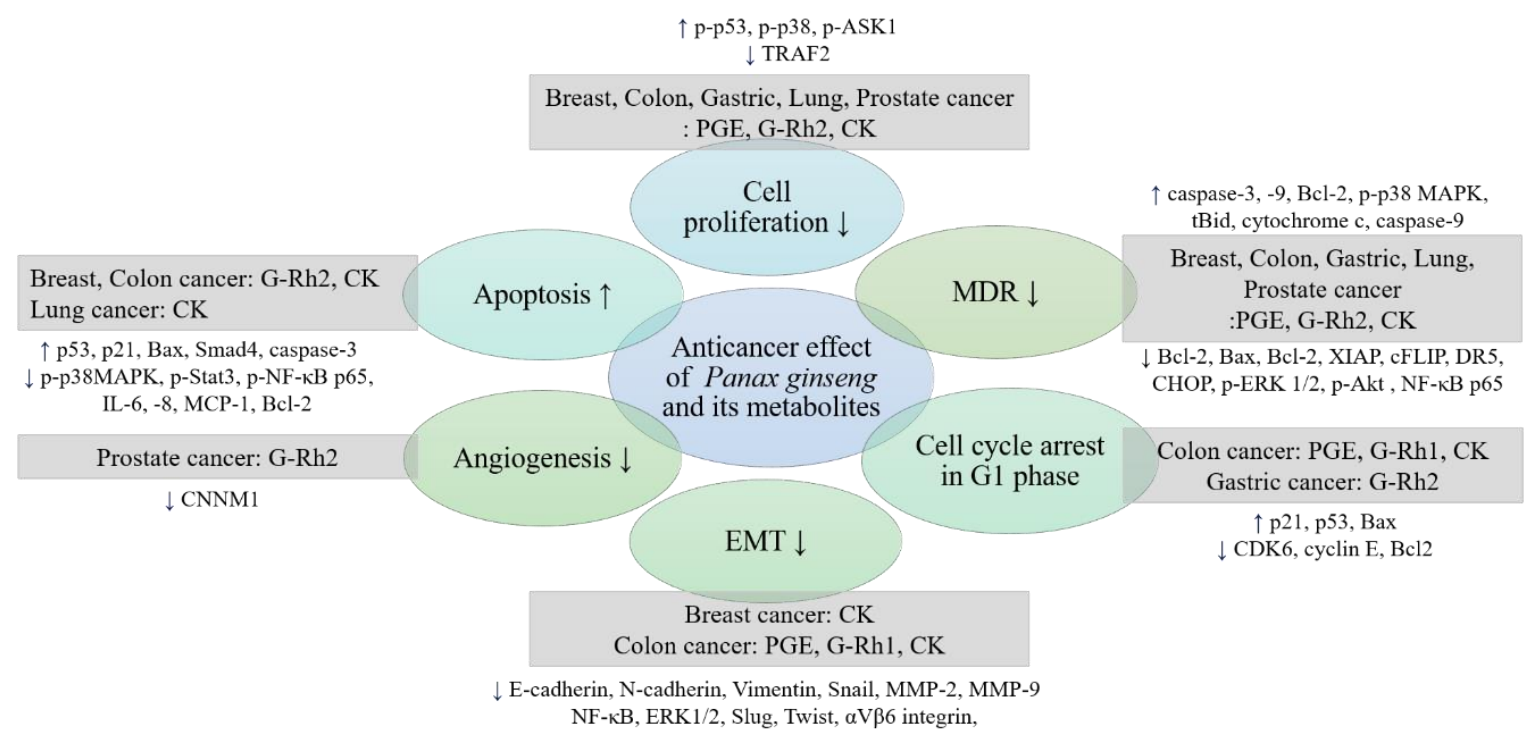

Figure 3. Schematic diagram of anti-cancer mechanisms of Panax ginseng and its metabolites. Panax ginseng and its metabolites mainly showed anticancer effects against the five major cancers through a wide range of mechanisms: The regulation of cell proliferation, apoptosis, angiogenesis, EMT (epithelial mesenchymal transition), cell cycle arrest in G1 phase, and MDR (multi-drug resistance). The figure above shows which substances follow each mechanism. Additionally, in relation to each mechanism, if there was a common factor confirmed to be regulated by each substance, it was indicated under and above the gray box. Bcl-2, B-cell lymphoma 2; CDK, cyclin-dependent kinases; CK, compound K; CNNM, cyclin and CBS domain divalent metal cation transport mediator; EMT, epithelial mesenchymal transition; ERK, extracellularsignal-regulated kinase; G-Rh, ginsenoside Rh; IL, interleukin; MAPK, mitogen-activated protein kinase; MCP, monocyte chemoattractant protein; MDR, multidrug resistance; MMP, matrix metalloproteinase; NF- $\mathrm{k}$, nuclear factor kappa B; p-ASK1, phosphorylated apoptosis signal-regulating kinase; PGE, panax ginseng extract; TRAF2, tumor necrosis factor receptor associated factor.

\subsection{Limitations}

There are limitations of the experiments reviewed in this study, which should be conducted again to verify the effects. First, although their putative metabolic pathways are suggested, studies that indicated bioavailability of ginsenoside metabolites are hardly known. Compound $\mathrm{K}$, metabolized ginsenoside $\mathrm{Rb}$, is absorbed in the liver and excreted as bile whereas ginsenoside F1 is absorbed into the mesenteric lymphatics [101,102]. Second, most of the anti-cancer effects of ginsenosides metabolites were conducted in vitro and there were few in vivo and only one clinical trial. These results are insufficient to powerfully demonstrate the efficacy of metabolites of ginsenosides. For more active application, further in vivo study and clinical trials are needed. Furthermore, considering the fact that actual anti-cancer treatment generally involves a combination of treatments, combination treatment studies should be conducted. Moreover, there were a few experiments in which drugs were administered at high concentrations. In the case of PGE, particularly, it was tested on colon cancer, and breast cancer at more than $100 \mu \mathrm{g} / \mathrm{mL}$ and as much as $5 \mathrm{mg} / \mathrm{mL}$. G-Rh2 also examined the effects of apoptosis and MDR with high dose administration at $250 \mu \mathrm{g} / \mathrm{mL}$ in LOVO cells. High concentration drug treatment could have toxicity to normal cells as well as cancer cells, thus further experiments should determine whether these effects can be achieved without side-effects. There were only two toxicity tests for normal cell lines when treating ginsenosides. Additional toxicity tests on normal cells are needed to ensure the safety of the drugs by grasping whether they areharmful to the body. This study reviews the effects of the metabolites of ginsenosides; CK, G-Rh1, G-Rh2, G-Rh3 
and F1 contained in PG, however, studies on G-Rh1, G-Rh3, and F1 did not exist. Both $\mathrm{CK}$ and G-Rh2 are ginsenoside metabolites in the PPD group, thus further experimental studies on ginsenosides metabolites in the PPT group are needed.

\section{Conclusions}

In this study, the possible anticancer effects of Panax ginseng and its metabolites against the five major cancers were reviewed. Panax ginseng and its metabolites mainly showed anticancer effects against the five major cancers through a wide range of mechanisms, the regulation of apoptosis, EMT (epithelial mesenchymal transition), angiogenesis, cell cycle arrest, and MDR (multidrug resistance). In particular, G-Rh2 showed anticancer effects in all five major carcinomas. These results might help to develop novel anti-cancer drugs that are specific to each cancer. However, most of these results are from in vitro and in vivo experiments. Further clinical trials are needed with PG and its metabolites.

Author Contributions: Investigation, S.K., N.K. and J.J.; data curation, S.K., N.K. and J.J.; writingoriginal draft preparation, S.K., N.K. and J.J.; writing-review and editing, S.K., S.L., W.K., S.-G.K. and B.K.; visualization, S.K., N.K. and J.J.; supervision, S.L., W.K., S.-G.K. and B.K.; project administration, B.K.; funding acquisition, S.-G.K. and B.K. All authors have read and agreed to the published version of the manuscript.

Funding: This research was supported by Basic Science Research Program through the National Research Foundation of Korea (NRF) funded by the Ministry of Education (NRF-2020R1I1A2066868), the National Research Foundation of Korea (NRF) grant funded by the Korea government (MSIT) (No. 2020R1A5A2019413), a grant of the Korea Health Technology R\&D Project through the Korea Health Industry Development Institute (KHIDI), funded by the Ministry of Health \& Welfare, Republic of Korea (grant number: HF20C0116), and a grant of the Korea Health Technology R\&D Project through the Korea Health Industry Development Institute (KHIDI), funded by the Ministry of Health \& Welfare, Republic of Korea (grant number: HF20C0038).

Institutional Review Board Statement: Not applicable.

Informed Consent Statement: Not applicable.

Data Availability Statement: Not applicable.

Conflicts of Interest: The authors declare no conflict of interest.

\section{References}

1. Bray, F.; Ferlay, J.; Soerjomataram, I.; Siegel, R.L.; Torre, L.A.; Jemal, A. Global cancer statistics 2018: GLOBOCAN estimates of incidence and mortality worldwide for 36 cancers in 185 countries. CA Cancer J. Clin. 2018, 68, 394-424. [CrossRef] [PubMed]

2. Torre, L.A.; Siegel, R.L.; Ward, E.M.; Jemal, A. Global Cancer Incidence and Mortality Rates and Trends-An Update. Cancer Epidemiol. Prev. Biomark. 2016, 25, 16-27. [CrossRef]

3. Donnelly, S.; Walsh, D. The symptoms of advanced cancer. Semin. Oncol. 1995, 22, 67.

4. Walsh, D.; Donnelly, S.; Rybicki, L. The symptoms of advanced cancer: Relationship to age, gender, and performance status in 1,000 patients. Support. Care Cancer 2000, 8, 175-179. [CrossRef]

5. Kwekkeboom, K.L. Cancer symptom cluster management. Semin. Oncol. Nurs. 2016, 32, 373-382. [CrossRef]

6. Paci, E.; Puliti, D.; Pegna, A.L.; Carrozzi, L.; Picozzi, G.; Falaschi, F.; Pistelli, F.; Aquilini, F.; Ocello, C.; Zappa, M. Mortality, survival and incidence rates in the ITALUNG randomised lung cancer screening trial. Thorax 2017, 72, 825-831. [CrossRef]

7. Gan, T.; Sinner, H.F.; Walling, S.C.; Chen, Q.; Huang, B.; Tucker, T.C.; Patel, J.A.; Evers, B.M.; Bhakta, A.S. Impact of the Affordable Care Act on colorectal cancer screening, incidence, and survival in Kentucky. J. Am. Coll. Surg. 2019, 228, 342-353. [CrossRef]

8. Oh, J.K.; Weiderpass, E. Infection and cancer: Global distribution and burden of diseases. Ann. Glob. Health 2014, 80, 384-392. [CrossRef] [PubMed]

9. Uemura, N.; Okamoto, S.; Yamamoto, S.; Matsumura, N.; Yamaguchi, S.; Yamakido, M.; Taniyama, K.; Sasaki, N.; Schlemper, R.J. Helicobacter pylori Infection and the Development of Gastric Cancer. N. Engl. J. Med. 2001, 345, 784-789. [CrossRef] [PubMed]

10. de Martel, C.; Ferlay, J.; Franceschi, S.; Vignat, J.; Bray, F.; Forman, D.; Plummer, M. Global burden of cancers attributable to infections in 2008: A review and synthetic analysis. Lancet Oncol. 2012, 13, 607-615. [CrossRef]

11. Coussens, L.M.; Werb, Z. Inflammation and cancer. Nature 2002, 420, 860-867. [CrossRef]

12. Shacter, E.; Weitzman, S.A. Chronic inflammation and cancer. Oncology 2002, 16, 217-226. [PubMed]

13. Chung, C.; Seo, W.; Silwal, P.; Jo, E.K. Crosstalks between inflammasome and autophagy in cancer. J. Hematol. Oncol. 2020, 13, 100. [CrossRef] 
14. Kojima, M.; Hosoda, H.; Date, Y.; Nakazato, M.; Matsuo, H.; Kangawa, K. Ghrelin is a growth-hormone-releasing acylated peptide from stomach. Nature 1999, 402, 656-660. [CrossRef] [PubMed]

15. Warzecha, Z.; Ceranowicz, P.; Dembinski, M.; Cieszkowski, J.; Ginter, G.; Ptak-Belowska, A.; Dembinski, A. Involvement of cyclooxygenase- 1 and cyclooxygenase-2 activity in the therapeutic effect of ghrelin in the course of ethanol-induced gastric ulcers in rats. J. Physiol. Pharmacol. 2014, 65, 95-106. [PubMed]

16. Frascarelli, S.; Ghelardoni, S.; Ronca-Testoni, S.; Zucchi, R. Effect of ghrelin and synthetic growth hormone secretagogues in normal and ischemic rat heart. Basic Res. Cardiol. 2003, 98, 401-405. [CrossRef]

17. Takeda, R.; Nishimatsu, H.; Suzuki, E.; Satonaka, H.; Nagata, D.; Oba, S.; Sata, M.; Takahashi, M.; Yamamoto, Y.; Terauchi, Y.; et al. Ghrelin improves renal function in mice with ischemic acute renal failure. J. Am. Soc. Nephrol. 2006, 17, 113-121. [CrossRef]

18. Warzecha, Z.; Kownacki, P.; Ceranowicz, P.; Dembinski, M.; Cieszkowski, J.; Dembinski, A. Ghrelin accelerates the healing of oral ulcers in non-sialoadenectomized and sialoadenectomized rats. J. Physiol. Pharmacol. 2013, 64, 657-668.

19. Stempniewicz, A.; Ceranowicz, P.; Warzecha, Z. Potential Therapeutic Effects of Gut Hormones, Ghrelin and Obestatin in Oral Mucositis. Int. J. Mol. Sci. 2019, 20, 1534. [CrossRef] [PubMed]

20. Warzecha, Z.; Ceranowicz, D.; Dembiński, A.; Ceranowicz, P.; Cieszkowski, J.; Kuwahara, A.; Kato, I.; Dembiński, M.; Konturek, P.C. Ghrelin accelerates the healing of cysteamine-induced duodenal ulcers in rats. Med Sci. Monit. 2012, 18, Br181-Br187. [CrossRef]

21. Bukowczan, J.; Warzecha, Z.; Ceranowicz, P.; Kusnierz-Cabala, B.; Tomaszewska, R.; Dembinski, A. Therapeutic effect of ghrelin in the course of ischemia/reperfusion-induced acute pancreatitis. Curr. Pharm. Des. 2015, 21, 2284-2290. [CrossRef]

22. Maduzia, D.; Matuszyk, A.; Ceranowicz, D.; Warzecha, Z.; Ceranowicz, P.; Fyderek, K.; Galazka, K.; Dembinski, A. The influence of pretreatment with ghrelin on the development of acetic-acid-induced colitis in rats. J. Physiol. Pharmacol. 2015, 66, 875-885. [PubMed]

23. Matuszyk, A.; Ceranowicz, P.; Warzecha, Z.; Cieszkowski, J.; Ceranowicz, D.; Gałązka, K.; Bonior, J.; Jaworek, J.; Bartuś, K.; Gil, K.; et al. Exogenous Ghrelin Accelerates the Healing of Acetic Acid-Induced Colitis in Rats. Int. J. Mol. Sci. 2016, 17, 1455. [CrossRef] [PubMed]

24. Kawaguchi, M.; Kanemaru, A.; Fukushima, T.; Yamamoto, K.; Tanaka, H.; Haruyama, Y.; Itoh, H.; Matsumoto, N.; Kangawa, K.; Nakazato, M.; et al. Ghrelin administration suppresses inflammation-associated colorectal carcinogenesis in mice. Cancer Sci. 2015, 106, 1130-1136. [CrossRef] [PubMed]

25. Shin, H.J.; Kim, D.H.; Zhong, X.; Yum, H.W.; Kim, S.J.; Chun, K.S.; Na, H.K.; Surh, Y.J. Preventive effects of Korean red ginseng on experimentally induced colitis and colon carcinogenesis. J. Tradit. Complement. Med. 2020, 10, 198-206. [CrossRef] [PubMed]

26. Ghobrial, I.M.; Witzig, T.E.; Adjei, A.A. Targeting apoptosis pathways in cancer therapy. CA Cancer J. Clin. 2005, 55, 178-194. [CrossRef]

27. Debatin, K.-M. Apoptosis pathways in cancer and cancer therapy. Cancer Immunol. Immunother. 2004, 53, 153-159. [CrossRef] [PubMed]

28. Kent, L.N.; Leone, G. The broken cycle: E2F dysfunction in cancer. Nat. Rev. Cancer 2019, 19, 326-338. [CrossRef]

29. Miller, K.D.; Nogueira, L.; Mariotto, A.B.; Rowland, J.H.; Yabroff, K.R.; Alfano, C.M.; Jemal, A.; Kramer, J.L.; Siegel, R.L. Cancer treatment and survivorship statistics, 2019. CA Cancer J. Clin. 2019, 69, 363-385. [CrossRef]

30. Schirrmacher, V. From chemotherapy to biological therapy: A review of novel concepts to reduce the side effects of systemic cancer treatment. Int. J. Oncol. 2019, 54, 407-419.

31. Kim, J.H.; Yi, Y.-S.; Kim, M.-Y.; Cho, J.Y. Role of ginsenosides, the main active components of Panax ginseng, in inflammatory responses and diseases. J. Ginseng Res. 2017, 41, 435-443. [CrossRef]

32. Kim, J.K.; Tabassum, N.; Uddin, M.R.; Park, S.U. Ginseng: A miracle sources of herbal and pharmacological uses. Orient. Pharm. Exp. Med. 2016, 16, 243-250. [CrossRef]

33. Hasegawa, H. Proof of the mysterious efficacy of ginseng: Basic and clinical trials: Metabolic activation of ginsenoside: Deglycosylation by intestinal bacteria and esterification with fatty acid. J. Pharmacol. Sci. 2004, 95, 153-157. [CrossRef]

34. Rajabian, A.; Rameshrad, M.; Hosseinzadeh, H. Therapeutic potential of Panax ginseng and its constituents, ginsenosides and gintonin, in neurological and neurodegenerative disorders: A patent review. Expert Opin. Ther. Pat. 2019, 29, 55-72. [CrossRef]

35. Kim, J.H. Pharmacological and medical applications of Panax ginseng and ginsenosides: A review for use in cardiovascular diseases. J. Ginseng Res. 2018, 42, 264-269. [CrossRef] [PubMed]

36. Baraya, Y.S.; Wong, K.K.; Yaacob, N.S. The Immunomodulatory Potential of Selected Bioactive Plant-Based Compounds in Breast Cancer: A Review. Anti Cancer Agents Med. Chem. 2017, 17, 770-783. [CrossRef]

37. Xiao, H.; Xue, Q.; Zhang, Q.; Li, C.; Liu, X.; Liu, J.; Li, H.; Yang, J. How Ginsenosides Trigger Apoptosis in Human Lung Adenocarcinoma Cells. Am. J. Chin. Med. 2019, 47, 1737-1754. [CrossRef] [PubMed]

38. Vayghan, H.J.; Ghadimi, S.S.; Nourazarian, A.R. Preventive and therapeutic roles of ginseng-focus on colon cancer. Asian Pac. J. Cancer Prev. 2014, 15, 585-588. [CrossRef]

39. Kim, H.S.; Kim, M.K.; Lee, M.; Kwon, B.S.; Suh, D.H.; Song, Y.S. Effect of Red Ginseng on Genotoxicity and Health-Related Quality of Life after Adjuvant Chemotherapy in Patients with Epithelial Ovarian Cancer: A Randomized, Double Blind, Placebo-Controlled Trial. Nutrients 2017, 9, 772. [CrossRef] [PubMed]

40. Shin, B.-K.; Kwon, S.W.; Park, J.H. Chemical diversity of ginseng saponins from Panax ginseng. J. Ginseng Res. 2015, 39, 287-298. [CrossRef] [PubMed] 
41. Qi, L.-W.; Wang, C.-Z.; Du, G.-J.; Zhang, Z.-Y.; Calway, T.; Yuan, C.-S. Metabolism of ginseng and its interactions with drugs. Curr. Drug Metab. 2011, 12, 818-822. [CrossRef]

42. Liu, H.; Yang, J.; Du, F.; Gao, X.; Ma, X.; Huang, Y.; Xu, F.; Niu, W.; Wang, F.; Mao, Y. Absorption and disposition of ginsenosides after oral administration of Panax notoginseng extract to rats. Drug Metab. Dispos. 2009, 37, 2290-2298. [CrossRef] [PubMed]

43. Takino, Y. Studies on the pharmacodynamics of ginsenoside-Rg1,-Rb1 and-Rb2 in rats. Yakugaku Zasshi J. Pharm. Soc. Jpn. 1994, 114, 550-564. [CrossRef]

44. Hasegawa, H.; Sung, J.-H.; Matsumiya, S.; Uchiyama, M. Main ginseng saponin metabolites formed by intestinal bacteria. Planta Med. 1996, 62, 453-457. [CrossRef]

45. Bae, E.-A.; Choo, M.-K.; Park, E.-K.; Park, S.-Y.; Shin, H.-Y.; Kim, D.-H. Metabolism of ginsenoside Rc by human intestinal bacteria and its related antiallergic activity. Biol. Pharm. Bull. 2002, 25, 743-747. [CrossRef]

46. Schabath, M.B.; Cote, M.L. Cancer Progress and Priorities: Lung Cancer. Cancer Epidemiol. Biomark. Prev. 2019, $28,1563-1579$. [CrossRef]

47. Yu, J.S.; Roh, H.-S.; Baek, K.-H.; Lee, S.; Kim, S.; So, H.M.; Moon, E.; Pang, C.; Jang, T.S.; Kim, K.H. Bioactivity-guided isolation of ginsenosides from Korean Red Ginseng with cytotoxic activity against human lung adenocarcinoma cells. J. Ginseng Res. 2018, 42, 562-570. [CrossRef] [PubMed]

48. Yoo, H.-S.; Kim, J.M.; Jo, E.; Cho, C.-K.; Lee, S.-Y.; Kang, H.S.; Lee, M.-G.; Yang, P.-Y.; Jang, I.-S. Modified Panax ginseng extract regulates autophagy by AMPK signaling in A549 human lung cancer cells. Oncol. Rep. 2017, 37, 3287-3296. [CrossRef]

49. Hwang, I.-H.; Kwon, Y.-K.; Cho, C.-K.; Lee, Y.-W.; Sung, J.-S.; Joo, J.-C.; Lee, K.-B.; Yoo, H.-S.; Jang, I.-S. Modified Panax ginseng extract inhibits uPAR-mediated $\alpha 5 \beta 1$-integrin signaling by modulating caveolin-1 to induce early apoptosis in lung cancer cells. Am. J. Chin. Med. 2016, 44, 1081-1097. [CrossRef] [PubMed]

50. Lee, D.G.; Jang, S.-I.; Kim, Y.-R.; Yang, K.E.; Yoon, S.J.; Lee, Z.-W.; An, H.J.; Jang, I.-S.; Choi, J.-S.; Yoo, H.-S. Anti-proliferative effects of ginsenosides extracted from mountain ginseng on lung cancer. Chin. J. Integr. Med. 2016, 22, 344-352. [CrossRef] [PubMed]

51. Jiang, S.-L.; Liu, H.-J.; Liu, Z.-C.; Liu, N.; Liu, R.; Kang, Y.-R.; Ji, J.-G.; Zhang, C.; Hua, B.-J.; Kang, S.-J. Adjuvant effects of fermented red ginseng extract on advanced non-small cell lung cancer patients treated with chemotherapy. Chin. J. Integr. Med. 2017, 23, 331-337. [CrossRef]

52. Li, Y.; Zhou, T.; Ma, C.; Song, W.; Zhang, J.; Yu, Z. Ginsenoside metabolite compound K enhances the efficacy of cisplatin in lung cancer cells. J. Thorac. Dis. 2015, 7, 400.

53. Jin, X.; Yang, Q.; Cai, N. Preparation of ginsenoside compound-K mixed micelles with improved retention and antitumor efficacy. Int. J. Nanomed. 2018, 13, 3827. [CrossRef]

54. Yang, L.; Zhang, Z.; Hou, J.; Jin, X.; Ke, Z.; Liu, D.; Du, M.; Jia, X.; Lv, H. Targeted delivery of ginsenoside compound K using TPGS/PEG-PCL mixed micelles for effective treatment of lung cancer. Int. J. Nanomed. 2017, 12, 7653. [CrossRef]

55. Rubio-Patino, C.; Bossowski, J.P.; De Donatis, G.M.; Mondragon, L.; Villa, E.; Aira, L.E.; Chiche, J.; Mhaidly, R.; Lebeaupin, C.; Marchetti, S.; et al. Low-Protein Diet Induces IRE1alpha-Dependent Anticancer Immunosurveillance. Cell Metab. 2018, 27, 828-842. [CrossRef]

56. Ge, G.; Yan, Y.; Cai, H. Ginsenoside Rh2 inhibited proliferation by inducing ROS mediated ER stress dependent apoptosis in lung cancer cells. Biol. Pharm. Bull. 2017, 40, 2117-2124. [CrossRef] [PubMed]

57. Wang, Y.; Xu, H.; Lu, Z.; Yu, X.; Lv, C.; Tian, Y.; Sui, D. Pseudo-Ginsenoside Rh2 induces A549 cells apoptosis via the Ras/Raf/ERK/p53 pathway. Exp. Ther. Med. 2018, 15, 4916-4924. [CrossRef] [PubMed]

58. Song, B.K.; Kim, K.M.; Choi, K.D.; Im, W.T. Production of the Rare Ginsenoside Rh2-MIX (20(S)-Rh2, 20(R)-Rh2, Rk2, and Rh3) by Enzymatic Conversion Combined with Acid Treatment and Evaluation of Its Anti-Cancer Activity. J. Microbiol. Biotechnol. 2017, 27, 1233-1241. [CrossRef] [PubMed]

59. Kwak, J.H.; Park, J.Y.; Lee, D.; Kwak, J.Y.; Park, E.H.; Kim, K.H.; Park, H.J.; Kim, H.Y.; Jang, H.J.; Ham, J.; et al. Inhibitory effects of ginseng sapogenins on the proliferation of triple negative breast cancer MDA-MB-231 cells. Bioorg. Med. Chem. Lett. 2014, 24, 5409-5412. [CrossRef] [PubMed]

60. Shibata, S.; Fujita, M.; Itokawa, H.; Tanaka, O.; Ishii, T. Studies on the Constituents of Japanese and Chinese Crude Drugs. XI. Panaxadiol, A Sapogenin of Ginseng Roots. Chem. Pharm. Bull. 1963, 11, 6. [CrossRef]

61. Oh, J.; Jeon, S.B.; Lee, Y.; Lee, H.; Kim, J.; Kwon, B.R.; Yu, K.Y.; Cha, J.D.; Hwang, S.M.; Choi, K.M.; et al. Fermented red ginseng extract inhibits cancer cell proliferation and viability. J. Med. Food 2015, 18, 421-428. [CrossRef]

62. Oh, J.; Yoon, H.J.; Jang, J.H.; Kim, D.H.; Surh, Y.J. The standardized Korean Red Ginseng extract and its ingredient ginsenoside Rg3 inhibit manifestation of breast cancer stem cell-like properties through modulation of self-renewal signaling. J. Ginseng Res. 2019, 43, 421-430. [CrossRef] [PubMed]

63. Kwak, C.W.; Son, Y.M.; Gu, M.J.; Kim, G.; Lee, I.K.; Kye, Y.C.; Kim, H.W.; Song, K.D.; Chu, H.; Park, B.C.; et al. A Bacterial Metabolite, Compound K, Induces Programmed Necrosis in MCF-7 Cells via GSK3beta. J. Microbiol. Biotechnol. 2015, 25, 1170-1176. [CrossRef]

64. Zhang, K.; Li, Y. Effects of ginsenoside compound K combined with cisplatin on the proliferation, apoptosis and epithelial mesenchymal transition in MCF-7 cells of human breast cancer. Pharm. Biol. 2016, 54, 561-568. [CrossRef] [PubMed]

65. Lee, H.; Lee, S.; Jeong, D.; Kim, S.J. Ginsenoside Rh2 epigenetically regulates cell-mediated immune pathway to inhibit proliferation of MCF-7 breast cancer cells. J. Ginseng Res. 2018, 42, 455-462. [CrossRef] 
66. Hou, J.G.; Jeon, B.M.; Yun, Y.J.; Cui, C.H.; Kim, S.C. Ginsenoside Rh2 Ameliorates Doxorubicin-Induced Senescence Bystander Effect in Breast Carcinoma Cell MDA-MB-231 and Normal Epithelial Cell MCF-10A. Int. J. Mol. Sci. 2019, 20, 1244. [CrossRef]

67. Zhang, H.; Gong, J.; Zhang, H.; Kong, D. Induction of apoptosis and reversal of permeability glycoprotein-mediated multidrug resistance of MCF-7/ADM by ginsenoside Rh2. Int. J. Clin. Exp. Pathol. 2015, 8, 4444-4456. [PubMed]

68. Ren, G.; Shi, Z.; Teng, C.; Yao, Y. Antiproliferative Activity of Combined Biochanin A and Ginsenoside Rh(2) on MDA-MB-231 and MCF-7 Human Breast Cancer Cells. Molecules 2018, 23, 2908. [CrossRef] [PubMed]

69. Wen, X.; Zhang, H.D.; Zhao, L.; Yao, Y.F.; Zhao, J.H.; Tang, J.H. Ginsenoside Rh2 differentially mediates microRNA expression to prevent chemoresistance of breast cancer. Asian Pac. J. Cancer Prev. 2015, 16, 1105-1109. [CrossRef]

70. Terzic, J.; Grivennikov, S.; Karin, E.; Karin, M. Inflammation and colon cancer. Gastroenterology 2010, 138, 2101-2114. [CrossRef]

71. Kim, E.J.; Kwon, K.A.; Lee, Y.E.; Kim, J.H.; Kim, S.H.; Kim, J.H. Korean Red Ginseng extract reduces hypoxia-induced epithelialmesenchymal transition by repressing NF-kappaB and ERK1/2 pathways in colon cancer. J. Ginseng Res. 2018, 42, 288-297. [CrossRef]

72. Li, T.; Sun, W.; Dong, X.; Yu, W.; Cai, J.; Yuan, Q.; Shan, L.; Efferth, T. Total ginsenosides of Chinese ginseng induces cell cycle arrest and apoptosis in colorectal carcinoma HT-29 cells. Oncol. Lett. 2018, 16, 4640-4648. [CrossRef] [PubMed]

73. Kee, J.Y.; Han, Y.H.; Mun, J.G.; Um, J.Y.; Hong, S.H. Pharmacological effect of prohibited combination pair Panax ginseng and Veratrum nigrum on colorectal metastasis in vitro and in vivo. J. Ethnopharmacol. 2018, 220, 177-187. [CrossRef] [PubMed]

74. Yao, H.; Wan, J.Y.; Zeng, J.; Huang, W.H.; Sava-Segal, C.; Li, L.; Niu, X.; Wang, Q.; Wang, C.Z.; Yuan, C.S. Effects of compound K, an enteric microbiome metabolite of ginseng, in the treatment of inflammation associated colon cancer. Oncol. Lett. 2018, 15, 8339-8348. [CrossRef]

75. Slattery, M.L.; Mullany, L.E.; Sakoda, L.C.; Wolff, R.K.; Samowitz, W.S.; Herrick, J.S. Dysregulated genes and miRNAs in the apoptosis pathway in colorectal cancer patients. Apoptosis 2018, 23, 237-250. [CrossRef] [PubMed]

76. Tischlerova, V.; Kello, M.; Budovska, M.; Mojzis, J. Indole phytoalexin derivatives induce mitochondrial-mediated apoptosis in human colorectal carcinoma cells. World J. Gastroenterol. 2017, 23, 4341-4353. [CrossRef] [PubMed]

77. Chen, L.; Meng, Y.; Sun, Q.; Zhang, Z.; Guo, X.; Sheng, X.; Tai, G.; Cheng, H.; Zhou, Y. Ginsenoside compound K sensitizes human colon cancer cells to TRAIL-induced apoptosis via autophagy-dependent and -independent DR5 upregulation. Cell Death Dis. 2016, 7, e2334. [CrossRef]

78. Yang, J.; Yuan, D.; Xing, T.; Su, H.; Zhang, S.; Wen, J.; Bai, Q.; Dang, D. Ginsenoside Rh2 inhibiting HCT116 colon cancer cell proliferation through blocking PDZ-binding kinase/T-LAK cell-originated protein kinase. J. Ginseng Res. 2016, 40, 400-408. [CrossRef]

79. Zhu, C.; Liu, F.; Qian, W.; Zhang, T.; Li, F. Combined Effect of Sodium Selenite and Ginsenoside Rh2 on HCT116 Human Colorectal Carcinoma Cells. Arch. Iran. Med. 2016, 19, 23-29.

80. Han, S.; Jeong, A.J.; Yang, H.; Bin Kang, K.; Lee, H.; Yi, E.H.; Kim, B.H.; Cho, C.H.; Chung, J.W.; Sung, S.H.; et al. Ginsenoside 20(S)-Rh2 exerts anti-cancer activity through targeting IL-6-induced JAK2/STAT3 pathway in human colorectal cancer cells. J. Ethnopharmacol. 2016, 194, 83-90. [CrossRef]

81. Liu, G.W.; Liu, Y.H.; Jiang, G.S.; Ren, W.D. The reversal effect of Ginsenoside Rh2 on drug resistance in human colorectal carcinoma cells and its mechanism. Hum. Cell 2018, 31, 189-198. [CrossRef]

82. Ma, J.; Gao, G.; Lu, H.; Fang, D.; Li, L.; Wei, G.; Chen, A.; Yang, Y.; Zhang, H.; Huo, J. Reversal effect of ginsenoside Rh2 on oxaliplatin-resistant colon cancer cells and its mechanism. Exp. Ther. Med. 2019, 18, 630-636. [CrossRef]

83. Gao, Q.; Zheng, J. Ginsenoside Rh2 inhibits prostate cancer cell growth through suppression of microRNA-4295 that activates CDKN1A. Cell Prolif. 2018, 51, e12438. [CrossRef]

84. Tong-Lin Wu, T.; Tong, Y.C.; Chen, I.H.; Niu, H.S.; Li, Y.; Cheng, J.T. Induction of apoptosis in prostate cancer by ginsenoside Rh2. Oncotarget 2018, 9, 11109-11118. [CrossRef]

85. Huang, Y.; Huang, H.; Han, Z.; Li, W.; Mai, Z.; Yuan, R. Ginsenoside Rh2 Inhibits Angiogenesis in Prostate Cancer by Targeting CNNM1. J. Nanosci. Nanotechnol. 2019, 19, 1942-1950. [CrossRef]

86. Zhang, Q.; Hong, B.; Wu, S.; Niu, T. Inhibition of prostatic cancer growth by ginsenoside Rh2. Tumor Biol. 2015, 36, 2377-2381. [CrossRef] [PubMed]

87. Hwang, J.W.; Baek, Y.M.; Jang, I.S.; Yang, K.E.; Lee, D.G.; Yoon, S.J.; Rho, J.; Cho, C.K.; Lee, Y.W.; Kwon, K.R.; et al. An enzymatically fortified ginseng extract inhibits proliferation and induces apoptosis of KATO3 human gastric cancer cells via modulation of Bax, mTOR, PKB and IkappaBalpha. Mol. Med. Rep. 2015, 11, 670-676. [CrossRef] [PubMed]

88. Qian, J.; Li, J.; Jia, J.G.; Jin, X.; Yu, D.J.; Guo, C.X.; Xie, B.; Qian, L.Y. Ginsenoside-Rh2 Inhibits Proliferation and Induces Apoptosis of Human Gastric Cancer SGC-7901 Side Population Cells. Asian Pac. J. Cancer Prev. 2016, 17, 1817-1821. [CrossRef] [PubMed]

89. Wild, C.; Weiderpass, E.; Stewart, B. World Cancer Report: Cancer Research for Cancer Prevention. World Cancer Reports. Lyon Int. Agency Res. Cancer; World Health Organization: Geneva, Switzerland, 2020.

90. Shin, H.R.; Kim, J.Y.; Yun, T.K.; Morgan, G.; Vainio, H. The cancer-preventive potential of Panax ginseng: A review of human and experimental evidence. Cancer Causes Control. 2000, 11, 565-576. [CrossRef]

91. Yu, K.; Chen, F.; Li, C. Absorption, disposition, and pharmacokinetics of saponins from Chinese medicinal herbs: What do we know and what do we need to know more? Curr. Drug Metab. 2012, 13, 577-598. [CrossRef] 
92. Chaabane, W.; User, S.D.; El-Gazzah, M.; Jaksik, R.; Sajjadi, E.; Rzeszowska-Wolny, J.; Łos, M.J. Autophagy, apoptosis, mitoptosis and necrosis: Interdependence between those pathways and effects on cancer. Arch. Immunol. Ther. Exp. 2013, 61, 43-58. [CrossRef] [PubMed]

93. Bilgi, N.; Bell, K.; Ananthakrishnan, A.N.; Atallah, E. Imatinib and Panax ginseng: A potential interaction resulting in liver toxicity. Ann. Pharmacother. 2010, 44, 926-928. [CrossRef]

94. Myers, A.P.; Watson, T.A.; Strock, S.B. Drug reaction with eosinophilia and systemic symptoms syndrome probably induced by a lamotrigine-ginseng drug interaction. Pharmacother. J. Hum. Pharmacol. Drug Ther. 2015, 35, e9-e12. [CrossRef]

95. Yan, Z.; Lai, Z.; Lin, J. Anticancer properties of traditional Chinese medicine. Comb. Chem. High Throughput Screen. 2017, 20, 423-429. [CrossRef]

96. Smith, B.N.; Bhowmick, N.A. Role of EMT in metastasis and therapy resistance. J. Clin. Med. 2016, 5, 17. [CrossRef]

97. Cort, A.; Ozben, T. Natural product modulators to overcome multidrug resistance in cancer. Nutr. Cancer 2015, 67, 411-423. [CrossRef]

98. Li, X.; Chu, S.; Lin, M.; Gao, Y.; Liu, Y.; Yang, S.; Zhou, X.; Zhang, Y.; Hu, Y.; Wang, H.; et al. Anticancer property of ginsenoside Rh2 from ginseng. Eur. J. Med. Chem. 2020, 203, 112627. [CrossRef] [PubMed]

99. Amaravadi, R.K.; Yu, D.; Lum, J.J.; Bui, T.; Christophorou, M.A.; Evan, G.I.; Thomas-Tikhonenko, A.; Thompson, C.B. Autophagy inhibition enhances therapy-induced apoptosis in a Myc-induced model of lymphoma. J. Clin. Investig. 2007, 117, 326-336. [CrossRef]

100. Amaravadi, R.K.; Thompson, C.B. The roles of therapy-induced autophagy and necrosis in cancer treatment. Clin. Cancer Res. 2007, 13, 7271-7279. [CrossRef] [PubMed]

101. Hasegawa, H.; Suzuki, R.; Nagaoka, T.; Tezuka, Y.; Kadota, S.; Saiki, I. Prevention of growth and metastasis of murine melanoma through enhanced natural-killer cytotoxicity by fatty acid-conjugate of protopanaxatriol. Biol. Pharm. Bull. 2002, 25, 861-866. [CrossRef] [PubMed]

102. Hasegawa, H.; Lee, K.-S.; Nagaoka, T.; TEZUKA, Y.; UCHIYAMA, M.; KADOTA, S.; SAIKI, I. Pharmacokinetics of ginsenoside deglycosylated by intestinal bacteria and its transformation to biologically active fatty acid esters. Biol. Pharm. Bull. 2000, 23, 298-304. [CrossRef] [PubMed] 